\title{
Bioconversion of Wood Waste to Bio-ethylene: A Review
}

\author{
Carolina Mónica Mendieta, Rocío Elizabet Cardozo, Fernando Esteban Felissia, Nicolás
}

Martín Clauser, María Evangelina Vallejos, and María Cristina Area *

\begin{abstract}
Bio-based ethylene produced by bioethanol dehydration is an environmentally friendly substitute for oil-based ethylene. It is a lowpollution raw material that can be used to produce high-value bio-based materials. Currently, some industrial plants use first-generation (1G) bioethanol to produce bio-ethylene. However, second-generation (2G) bioethanol is not currently used to produce bio-ethylene because the manufacturing processes are not optimized. The conversion of lignocellulosic biomass to bio-ethylene involves pretreatment, enzymatic hydrolysis of carbohydrates, the fermentation of sugars to ethanol, ethanol recovery by distillation, and ethanol dehydration to ethylene. This work presents a review of second-generation (2G) bio-ethylene production, analyzing the stages of the process, possible derivatives, uses, and applications. This review also contains technical, economic, and environmental considerations in the possible installation of a biorefinery in the northeast region of Argentina (NEA).
\end{abstract}

Keywords: Biorefinery; Lignocellulosic biomass; Bioethanol; Bio-ethylene

Contact information: IMAM, UNAM, CONICET, FCEQYN, Programa de Celulosa y Papel (PROCYP), Misiones, Argentina, Félix de Azara 1552, Posadas, Argentina;

* Corresponding author: cristinaarea@gmail.com

\section{INTRODUCTION}

Ethylene is a chemical building block that is heavily employed in the petrochemical sector. Ethylene is traditionally obtained by cracking of the hydrocarbons from petroleum using steam (Kniel et al. 1980) and is recovered from refinery cracked gas (Zimmermann and Walzl 2000). In recent years, researchers have focused on sustainable alternatives to ethylene to decrease greenhouse gas (GHG) emissions and reduce the dependency on fossil fuels (Melander and Qvint 2016).

Bioethanol is a renewable and environmentally friendly source for energy and highvalue derivatives. Additionally, bioethanol's catalytic dehydration is a sustainable alternative for bio-ethylene production (Fan et al. 2013). Bioethanol dehydration could be a more sustainable and less expensive pathway for bio-ethylene production compared to the oil-based pathway (Becerra et al. 2017).

First-generation (1G) bioethanol is produced from sugar-rich and renewable feedstock resources, such as sugarcane, corn grains, potatoes, wheat, cassava, and sugar beet, among other crops (Hettinga et al. 2009; Kagyrmanova et al. 2011; Haro et al. 2013; McKechnie et al. 2015; Mohsenzadeh et al. 2017; Zacharopoulou and Lemonidou 2017). On the other hand, second-generation $(2 \mathrm{G})$ bioethanol may provide an opportunity to develop sustainable biorefineries (Adekunle et al. 2016; Vallejos et al. 2017; Mendes et al. 2020). Compared to gasoline production, bioethanol production has a positive net-energy 
output (64\% to $86 \%$ ) and can reduce GHG emissions by $11 \%$ to $145 \%$ (Werpy and Petersen 2004). Due to its added-value and potential market demand, bioethanol is one of the best candidates as a base for biorefinery products (Huang et al. 2011; Pérez et al. 2020). Secondgeneration bio-ethylene is made from non-alimentary carbohydrates by the conversion of low-cost agroforestry residues that favor its valorization (Alvarez-Castillo et al. 2012). The main routes to convert carbohydrate biomass to bioethanol, bio-ethylene, and polyolefins are displayed in Fig. 1.

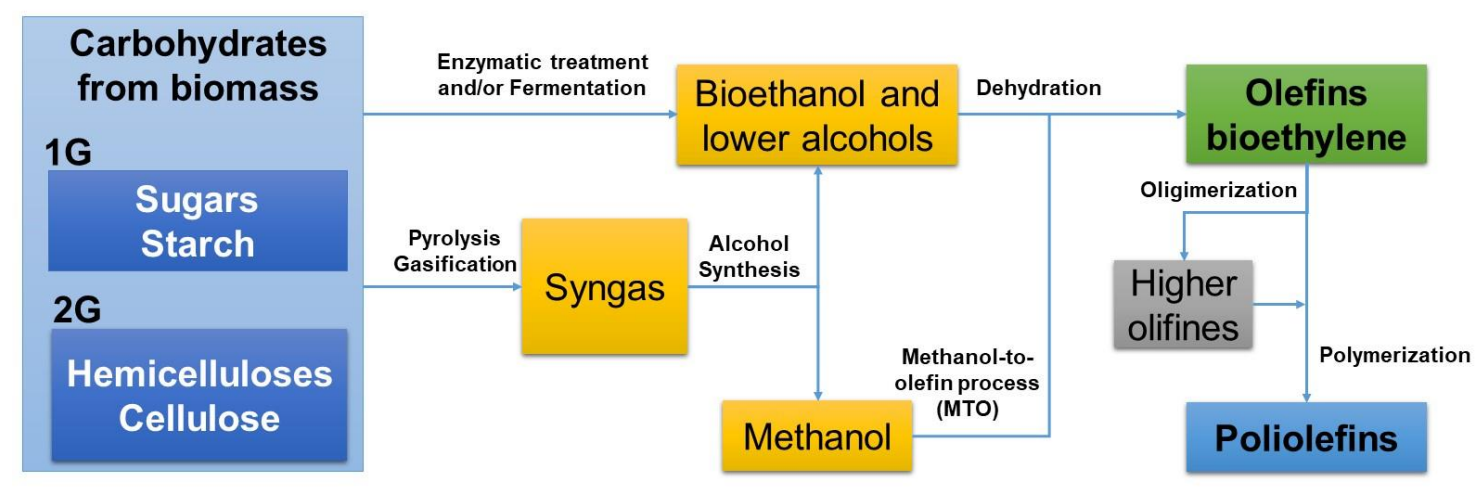

Fig. 1. The production process to make bio-ethylene and polyolefins from carbohydrate biomass (adapted from Grassi et al. 2015).

Ethanol is an important industrial commodity, and its chemical potential to generate an ethylene platform is enormous and among the top opportunities from carbohydrate biorefineries. The bio-ethylene from $1 \mathrm{G}$ or $2 \mathrm{G}$ ethanol is chemically identical to the oilbased one, but it is produced from a different carbon source. Technological improvements are necessary to attain the commercial scale production from $2 \mathrm{G}$ ethanol. The high yield catalysts need to be improved and the costs of the feedstocks and processes need to decrease (de Andrade Coutinho et al. 2013).

The northeast region of Argentina (NEA) is the largest forested area of the country. The Province of Misiones, with 405,824 ha planted (mostly pines), has an important forestindustrial activity. It accounts for $46 \%$ of the country's sawmills, which produce large amounts of lignocellulosic residues (sawdust, bark, others). These lignocellulosic residues create pollution, increase the risks of fire, increase the presence of pests, and the disposal of the residue occupies valuable space (Vallejos et al. 2017; Pérez et al. 2020). Currently, the concept of biorefinery and biomass residue valorization can add value to the forestindustrial cycle due to the large quantities of waste materials that are rich in sugars, lignin, lipids, and proteins (Area and Vallejos 2012; Area and Park 2017). Agro-industrial and forest industrial lignocellulosic residues are valuable feedstocks for ethylene production from $2 \mathrm{G}$ bioethanol.

This work analyzes the stages, possible derivatives, uses, and applications of $2 \mathrm{G}$ bio-ethylene production within a biorefinery framework. An extensive bibliographic review was carried out, and the potential replacement of fossil-fuel-based ethylene from $2 \mathrm{G}$ bio-ethylene was evaluated. The technical, economic, and environmental implications of the production of ethylene from biomass were established, considering the biomass available in Argentina's NEA region as a case study. 


\section{BIO-ETHYLENE MARKET}

Ethylene is a highly reactive unsaturated hydrocarbon (alkene), which makes it a potential chemical building block. Ethylene can typically react as a short-chain olefin, from which it can produce mixtures of different compounds during its production process, which should be further separated (Zimmermann and Walzl 2000). Ethylene is primarily used in the transportation, textiles, packaging, and electronics industries, among others (WileyVCH 2016). Currently, there is a strong demand for ethylene use in bioplastic production (Martinz and Quadros 2008; Mendieta et al. 2019). The ability to close the biorefinery scheme can be valuable to produce derivatives such as bio-polyethylene (bioPE), biopolyvinyl chloride (bioPVC), bio-polyethylene terephthalate (bioPET), bio- polypropylene (bioPP), and others (Area and Park 2017; Brodin et al. 2017). In addition to the production of polymers, bio-ethylene can be used in the chemical industry as an intermediate compound in the synthesis of alcohols, olefins, acetaldehyde $\left(\mathrm{C}_{2} \mathrm{H}_{4} \mathrm{O}\right)$, ethylbenzene, and vinyl acetate, among others (Zimmermann and Walzl 2000). The industrial processes with high ethylene consumption are the polymerization to low-density polyethylene (LDPE) and high-density polyethylene (HDPE), the chlorination to 1,2-dichloroethane, the oxidation to ethylene oxide (EO), the sequential reaction to form ethylbenzene that is dehydrogenated to styrene, the oxidation process to $\mathrm{C}_{2} \mathrm{H}_{4} \mathrm{O}$, and the hydration reaction to ethanol, among others (Zimmermann and Walzl 2000).

The current annual global production capacity of ethylene is over 140 to 150 million tons (Alonso-Fariñas et al. 2018; Oliveira et al. 2019). The ethylene market size was approximately $\$ 160,000$ million USD in 2015 and it is estimated to exceed $\$ 235,000$ million USD in 2024 (Global Market Insights 2016). The selling price of ethylene fluctuated between 2018 and 2019. It decreased by $15 \%$ to 35\%, reaching \$1,000 USD/t in May 2019 (ICIS 2020), mainly due to the decrease in oil prices (Min-hee 2019; Hall 2020).

There are several polymer derivatives of ethylene that are used in various applications. Polyethylene (PE) is used in packaging, stretch films, containers, drums, pallets, and other applications (Wiley-VCH 2016). Ethylene oxide is used to produce polyester fibers, resins, and polyester films, among others (Graham et al. 1989). Polypropylene (PP) is used to produce films, sheets, foamed products, industrial products, reinforced products, and containers, among others (Kikuchi et al. 2017). Polyethylene terephthalate (PET) is mainly in the production of soda bottles and many other packaging materials (Spencer 1994). Polyvinyl chloride (PVC) is used to manufacture packaging containers and bottles (Spencer 1994; Wiley-VCH 2016). Polystyrene (PS) is used to produce electronic and electrical equipment (Thakur et al. 2018).

Polyethylene accounts for $60 \%$ of the global ethylene demand, followed by EO. Both PE and EO are used to make ethylene glycol (ICIS 2010). The common prices for PE derivatives are between $\$ 1,100 \mathrm{USD} / \mathrm{t}$ and $\$ 1,300 \mathrm{USD} / \mathrm{t}$ for LDPE (ICIS 2019; Santagata et al. 2020) and $\$ 1,150 \mathrm{USD} / \mathrm{t}$ to $\$ 1,400 \mathrm{USD} / \mathrm{t}$ for HDPE (ICIS 2019). The reported market prices for ethylene glycol and PP are approximately $\$ 0.4 \mathrm{USD} / \mathrm{t}$ to $\$ 1.4 \mathrm{USD} / \mathrm{t}$ and $\$ 1,500$ USD/t, respectively. (ICIS 2013; Taylor et al. 2015; Echemi 2021).

Besides polymer production, ethylene is used in many applications. To give some examples, it is used to control the ripening of fruit, to promote crop growth in agriculture, in the production of specialty glass for the automotive industry, as an anesthetic in medical applications, as a refrigerant, and as oxy-fuel gas in metal works (Keller et al. 2013).

The hydrocarbon cracking process to obtain ethylene requires intensive fossil energy use, which has a large environmental impact. Steam cracking might create an 
economic impediment for further developments of bio-based ethylene production. Nevertheless, research on technologies for the dehydration of ethanol in ethylene continues to advance. On the other hand, small-scale production could be an interesting niche since full-scale crackers (using either naphtha or natural gas) would not be commercially viable. In this sense, bio-ethylene production might be commercially viable due to the possibility of using the current conversion and production equipment, besides the necessity of process optimization. To meet this demand, several companies have researched and patented various technologies for the dehydration of ethanol into ethylene (Chieregato et al. 2016). Moreover, there is less need for development of the supply chain and logistics for the provisions of raw materials and inputs (Wyman et al. 2017). The current global demand for $1 \mathrm{G}$ bio-ethylene market is 127 million tons per year. Approximately $0.2 \%$ of this demand (0.25 million tons per year) comes from biomass resources (Kagyrmanova et al. 2011; Broeren 2013).

In the polymer field, the non-biodegradable, versatile, and chemically stable bio$\mathrm{PE}$ and bio-PET materials have gained interest in recent years (de Jong et al. 2012b; Hottle et al. 2013; Iwata 2015; Mendieta et al. 2019). Coca-Cola's commercial bottling plant currently utilizes bio-PET (Taylor et al. 2015). Toyota also uses bio-PET for the production of the interior surfaces and liner material in their vehicles (de Jong et al. 2012a). Biopolyethylene can substitute petroleum-based PE in several applications (Mendieta et al. 2019), so bio-PE may soon become the most widely used bio-based plastic (Taylor et al. 2015). Currently, the prices of fossil-fuel-based PE are lower and they can be processed more easily than bio-PE materials (Taylor et al. 2015). Therefore, process improvements in the manufacturing of bio-PE and bio-PET are necessary to ensure they can compete with fossil-fuel based plastics.

\section{G BIOETHANOL PRODUCTION}

Ethylene production by $2 \mathrm{G}$ bioethanol dehydration, using forest or agro-industrial waste is a sustainable alternative to oil-based one (Santos-Panqueva et al. 2017). Gasification of lignocellulosic biomass is a thermochemical route to produce bioethanol. Using chemical catalysts, the synthesis gas generates ethanol together with a mixture of alcohols. Another option to produce ethanol is the fermentation of the synthesis gas (Wagner and Kaltschmitt 2013). Compared with the SHF and SSF routes, gasification has some handicaps. It requires high temperatures, and both the moisture content of the raw material and the contaminants of the synthesis gas must be removed because of their negative impact on the performance of catalysts and fermentation broths. Therefore, the biochemical route is the most efficient one (Silva-Ortiz et al. 2020).

The ethylene production process consists of pretreatment, enzymatic hydrolysis, fermentation, recovery by distillation, and dehydration (Yakovleva et al. 2016). There are challenges to achieve commercial-scale production by $2 \mathrm{G}$ bioethanol dehydration, such as the selection of a suitable treatment of the lignocellulosic biomass to obtain a cellulosic fraction, the conversion process of cellulose to ethanol, and the fermentation selectivity. These processes have direct effects on the bioethanol yield and production cost (Saha 2003; Zhu et al. 2011; Broeren 2013). Moreover, efficiency increases if both pentose and hexose are converted in bioethanol (Sharma et al. 2020).

The conditions and type of pretreatment depend exclusively on the chemical composition of the feedstock (Kruyeniski et al. 2019), which has a significant influence on

Mendieta et al. (2021). "Wood wastes to bio-ethylene," BioResources 16(2), 4411-4437. 4414 
the enzymatic hydrolysis and following processes (Vallejos et al. 2017). For example, coniferous wood for $2 \mathrm{G}$ bioethanol production is attractive due to its abundance and high content of hexoses (Area et al. 2012; Kruyeniski et al. 2017). However, the pretreatment of coniferous wood can be hindered by its high lignin and extractives content and its highly crystalline cellulose (Stoffel 2016).

Before the production of $2 \mathrm{G}$ bioethanol, it is critical to pretreat the lignocellulosic biomass. An efficient pretreatment should apply to various substrates using cheap and easily recoverable reagents, with low energy consumption, and low investment and maintenance costs, among other features (Almenares-Verdecía et al. 2008). The reactions must favor the formation of sugars, avoid their loss by degradation, and limit the production of inhibitory products (Kumari and Singh 2018). New research should focus on developing new low-cost and environmentally-friendly pretreatment techniques to produce a purified cellulosic material with high yield. The pretreatment process extracts the lignin and hemicellulose in order to increase the porosity of the material to improve cellulose accessibility to the enzymatic attack. The pretreatment process should also limit the degradation of other carbohydrates and, in the saccharification stage, avoid the formation of inhibitor products (Kruyeniski et al. 2019).

The cellulose that is obtained from the pretreatment can be transformed into ethanol in two steps. Initially, cellulose is depolymerized to glucose by hydrolysis, and then these sugars are fermented into ethanol (Hahn-Hägerdal et al. 2006; Ximenes et al. 2011; Gu et al. 2014). Depending on the strains, the optimum temperature for the development of fermentation yeasts is usually between $25^{\circ} \mathrm{C}$ to $35^{\circ} \mathrm{C}$ (Palmqvist and Hahn-Hägerdal 2000). Saccharomyces cerevisiae is the most common yeast for industrial production because of its capability to efficiently ferment glucose and other hexoses to bioethanol. $S$. cerevisiae can withstand temperatures up to $38{ }^{\circ} \mathrm{C}$, but the fermentation performance decreases noticeably (Azhar et al. 2017). The high-temperature fermentation process is beneficial because it uses heat-tolerant microorganisms that do not incur cooling costs (Fonseca et al. 2008). Some microorganisms can withstand high temperatures. For example, Kluyveromyces marxianus is a thermotolerant yeast that can survive at $42{ }^{\circ} \mathrm{C}$ to $45{ }^{\circ} \mathrm{C}$, with the capacity to ferment both hexoses and pentoses (Yanase et al. 2010). The common pretreatment strategies of separate hydrolysis and fermentation (SHF) and simultaneous hydrolysis and fermentation (SSF) (Balat 2011) are shown in Fig. 2.

In the SHF process, cellulose hydrolysis and glucose fermentation are accomplished separately, which allows each stage to occur at its optimum conditions. However, the separate conditions are disadvantageous for the generation of inhibition products, such as glucose for hydrolysis and ethanol for fermentation (Araque et al. 2008; Kruyeniski 2017). On the other hand, the SSF process requires only one reactor for hydrolysis and fermentation. The SSF process is advantageous because the sugar monomers that are released during the saccharification process are immediately fermented by the microorganisms, which decreases the risk of microbial contamination (Area et al. 2012; von Schenck et al. 2013). Glucose is instantly fermented into ethanol (Becerra et al. 2017), regardless of the optimum temperature and the $\mathrm{pH}$ parameters for the hydrolysis and fermentation processes. Therefore, the SSF process is the most feasible and costeffective alternative to produce bioethanol considering the low generation of inhibitory products and the utilization of only one fermenter in the whole process, which reduces the investment costs (Wingren et al. 2003; Arismendy et al. 2018; Olofsson et al. 2008). Table 1 shows some examples of bioethanol yields using the SHF and SSF strategies.

Mendieta et al. (2021). "Wood wastes to bio-ethylene," BioResources 16(2), 4411-4437. 4415 


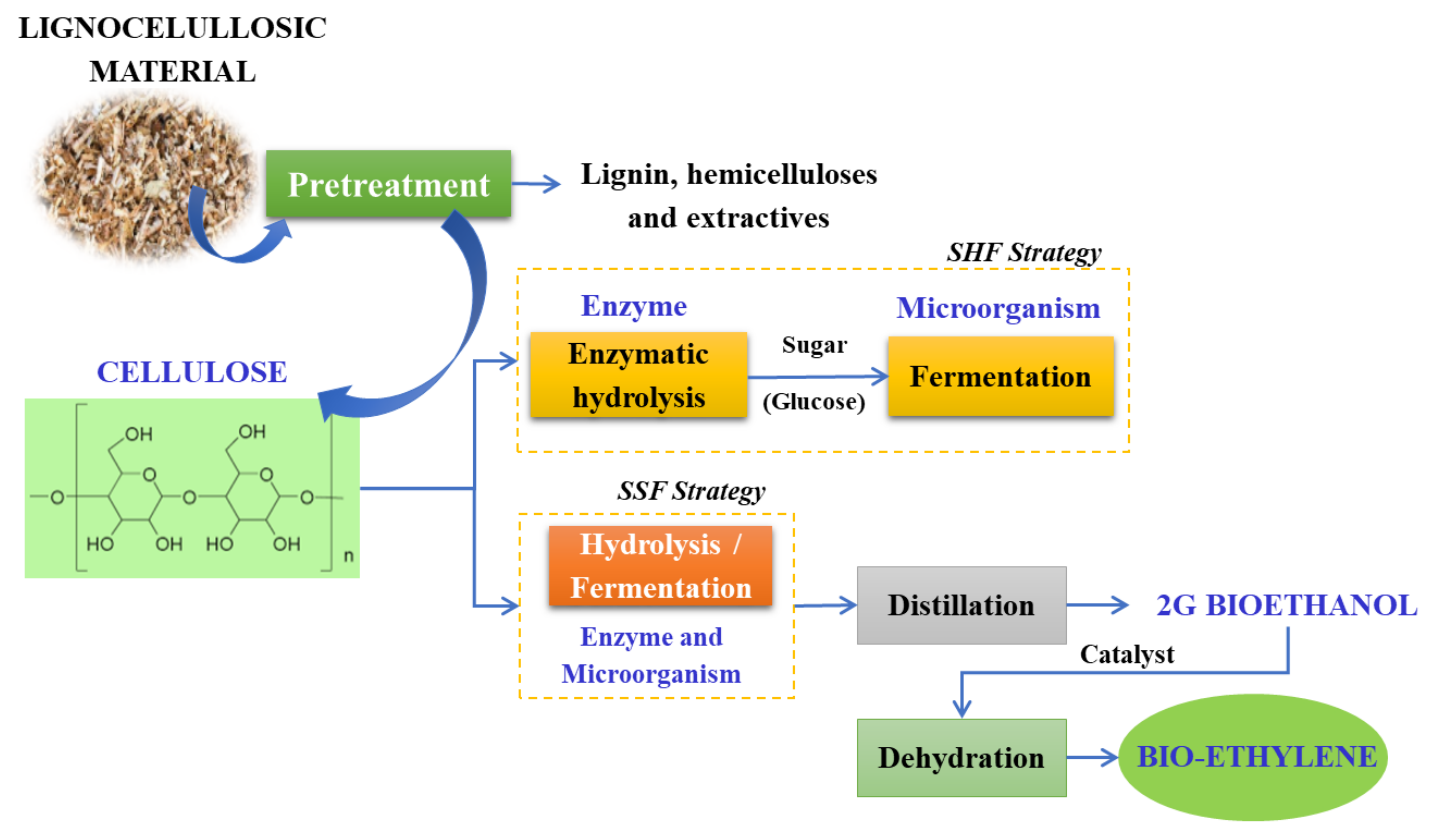

Fig. 2. The sequences of the $2 \mathrm{G}$ bio-ethylene production by the SHF and SSF strategies

Table 1. Various Bioethanol Yield (BEY) Values Obtained from SHF and SSF Strategies from Softwoods

\begin{tabular}{|c|c|c|c|c|c|c|}
\hline Raw Material & Origin & Strategy & BEY (\%) & Conditions & Scale & Reference \\
\hline \multirow[t]{2}{*}{$\begin{array}{l}\text { Pinus } \\
\text { pinaster } \\
\text { Stumps }\end{array}$} & \multirow[t]{2}{*}{ Portugal } & \multirow[t]{2}{*}{ SSF } & \multirow[t]{2}{*}{$97 \%$} & $\begin{array}{c}15 \text { (FPU)/g pulp Cellic® } \\
\text { Ctec2 (CTec2), } 72 \text { h, } 38 \\
{ }^{\circ} \mathrm{C}\end{array}$ & \multirow{2}{*}{$\begin{array}{l}250 \mathrm{~mL} \\
\text { Erlenmeyer } \\
\text { flasks, } 50 \\
\mathrm{~mL} \text { working } \\
\text { volume }\end{array}$} & \multirow[t]{2}{*}{$\begin{array}{l}\text { (Mendes et } \\
\text { al. 2020) }\end{array}$} \\
\hline & & & & S. cerevisiae & & \\
\hline \multirow{2}{*}{$\begin{array}{l}\text { Pinewood } \\
\text { chips }\end{array}$} & \multirow[t]{2}{*}{ Italy } & \multirow[t]{2}{*}{ SHF } & \multirow[t]{2}{*}{$96.1 \%$} & CTec2, $48 \mathrm{~h}, 50^{\circ} \mathrm{C}$ & \multirow{2}{*}{$\begin{array}{l}\text { Bioreactor } \\
\text { of } 6 \mathrm{~L} \\
\text { capacity }\end{array}$} & \multirow{2}{*}{$\begin{array}{l}\text { (Cotana et } \\
\text { al. 2014) }\end{array}$} \\
\hline & & & & S. cerevisiae, $48 \mathrm{~h}, 32^{\circ} \mathrm{C}$ & & \\
\hline \multirow{2}{*}{$\begin{array}{l}\text { Softwood } \\
\text { kraft } \\
\text { unbleached } \\
\text { pulp } \\
\end{array}$} & \multirow[t]{2}{*}{ Japan } & \multirow[t]{2}{*}{ SSF } & \multirow[t]{2}{*}{$62.8 \%$} & $\begin{array}{c}15(\mathrm{FPU}) / \mathrm{g} \text { pulp EPEG- } \\
\mathrm{SL}, 72 \mathrm{~h}, 38^{\circ} \mathrm{C}\end{array}$ & \multirow{2}{*}{$\begin{array}{l}100 \mathrm{~mL} \\
\text { scale fed- } \\
\text { batch }\end{array}$} & \multirow[t]{2}{*}{$\begin{array}{c}\text { (Cheng et al. } \\
\text { 2017) }\end{array}$} \\
\hline & & & & S. cerevisiae & & \\
\hline \multirow[t]{2}{*}{ Pinus radiata } & \multirow[t]{2}{*}{ Chile } & \multirow[t]{2}{*}{ SSF } & \multirow[t]{2}{*}{$95 \%$} & $\begin{array}{c}0.44 \mathrm{~g} \text { of Cellic } \AA \text { Ctec3 } \\
(\text { Ctec } 3) / \mathrm{g} \text { of dry substrate, } \\
72 \mathrm{~h}, 40^{\circ} \mathrm{C} \\
\end{array}$ & \multirow[t]{2}{*}{$\begin{array}{c}\text { Not } \\
\text { specified }\end{array}$} & \multirow[t]{2}{*}{$\begin{array}{l}\text { (Valenzuela } \\
\text { et al. 2016) }\end{array}$} \\
\hline & & & & Saccharomyces IR2-9 & & \\
\hline \multirow[t]{2}{*}{$\begin{array}{c}\text { Pinus } \\
\text { sylvestris }\end{array}$} & \multirow[t]{2}{*}{ Finland } & \multirow[t]{2}{*}{ SSF } & \multirow[t]{2}{*}{$87.8 \%$} & \begin{tabular}{|c|}
$10(\mathrm{FPU}) / \mathrm{g}$ pulp \\
Celluclast@ $1.5 \mathrm{~L}$ and \\
Novozyme $188(200 \mathrm{nkat} / \mathrm{g}$ \\
dry matter). $72 \mathrm{~h}, 40^{\circ} \mathrm{C}$ \\
\end{tabular} & \multirow{2}{*}{$\begin{array}{c}250 \mathrm{~mL} \\
\text { Erlenmeyer } \\
\text { flasks, } 100 \\
\text { mL working } \\
\text { volume }\end{array}$} & \multirow[t]{2}{*}{$\begin{array}{l}\text { (von } \\
\text { Schenck et } \\
\text { al. 2013) }\end{array}$} \\
\hline & & & & S. cerevisiae IR2-9 & & \\
\hline \multirow[t]{2}{*}{ Pine waste } & \multirow[t]{2}{*}{$\begin{array}{l}\text { Argen- } \\
\text { tina }\end{array}$} & \multirow[t]{2}{*}{ SHF } & \multirow[t]{2}{*}{$83 \%$} & $\begin{array}{c}\text { Trichoderma reseei (20 } \\
\text { FPU/g glucans), } 48 \mathrm{~h}, 50 \\
{ }^{\circ} \mathrm{C}\end{array}$ & \multirow[t]{2}{*}{$\begin{array}{l}50 \mathrm{~mL} \\
\text { Erlenmeyer } \\
\quad \text { flasks }\end{array}$} & \multirow[t]{2}{*}{$\begin{array}{l}\text { (Kruyeniski } \\
2017)\end{array}$} \\
\hline & & & & S. cerevisiae, $48 \mathrm{~h}, 30^{\circ} \mathrm{C}$ & & \\
\hline
\end{tabular}


High bioethanol yields are justified by low lignin content in the substrate (pretreated pulp), because of its low toxicity for both yeasts and enzymes (von Schenck et al. 2013). Mendes et al. (2020) reported ethanol yields of about $97 \%$ in the SSF strategy, using Pinus pinaster stumps. This was higher than that obtained by Cheng et al. (2017) $(62.8 \%)$ in the same conditions $\left(72 \mathrm{~h}, 38{ }^{\circ} \mathrm{C}\right.$, and enzyme charge).

Several fungi and bacteria for the hydrolysis of lignocellulosic biomass were studied to evaluate the possibility of producing ethylene at a commercial level. However, it was discarded because the obtained yields of ethylene were significantly low using wild yeasts (Penicillium digitatum and Pseudomonas syringae). Studies that utilized enzymes at the laboratory scale resulted in negligible ethylene yields, which illustrates that this process is not commercially applicable (Manikandan et al. 2016).

\section{BIO-ETHYLENE PRODUCTION FROM 2G BIOETHANOL}

In the petrochemical industry, dehydration of ethanol to ethylene is a usual process (Kniel et al. 1980). Nevertheless, for the ethylene process, ethanol purity must be higher than $95 \mathrm{wt} \%$. Besides, bioethanol has particularities that make necessary further treatment previous to ethylene processing. Unlike ethanol, both $1 \mathrm{G}$ and $2 \mathrm{G}$ bioethanol come from a fermentation broth that contains microorganisms, nutrients, and reaction by-products. The obtained bioethanol must be purified by removing contaminants and additional water. For this, several methods combine distillation, adsorption, extraction, among others, such as separation by membrane pervaporation (Feng and Huang 1997), extractive distillation (Mendoza- Pedroza et al. 2018), or heteroazeotropic distillation (Frolkova and Raeva 2010), which have been exhaustively described in the literature. For ethylene production, in particular, Very High Gravity (VHG) fermentation emerges as an interesting option to explore and optimize when using SHF, since it can improve fermentation performance and purify ethanol simultaneously (Kang et al. 2014b). Considering that this is a stage of great energy consumption (Cardona et al. 2006), it is one of the steps that require optimization to contribute to the economic viability of bio-ethylene.

Lignocellulosic biomass as a substrate could also contain reaction products from pretreatments, such as furfural and acetic acid, which could become bioethanol contaminant by carryover. However, a simulation carried out with the Aspen program showed that the impurity profile of ethanol feed does not have a significant effect on the quality of the obtained bio-ethylene (Mohsenzadeh et al. 2017). Experiences are needed to corroborate this supposition.

The process to manufacture bio-ethylene involves an endothermic reaction that occurs under adequate temperature and with the aid of a catalyst (Mohsenzadeh et al. 2017). The type of catalyst and the process conditions determine the extent of the side reactions. For example, the dehydrogenation of ethanol can produce $\mathrm{C}_{2} \mathrm{H}_{4} \mathrm{O}$ and hydrogen gas $\left(\mathrm{H}_{2}\right)$. Ethylene can be dimerized and oligomerized to $\mathrm{C} 4$ olefins, which can be hydrogenated to saturated hydrocarbons (mainly ethane). Other reactions involve impurities in the feedstock, such as the dehydration of heavier alcohols. A variety of reaction byproducts can be found in ethanol dehydration, including acetic acid, ethyl acetate, acetone, methanol, short hydrocarbons (methane, ethane, propane, propylene, others), $\mathrm{CO}$, and $\mathrm{CO}_{2}$, among others. These compounds impact the separation process and recovery costs.

Mendieta et al. (2021). "Wood wastes to bio-ethylene," BioResources 16(2), 4411-4437. 4417 
Ethylene is formed by the highly endothermic intramolecular dehydration of ethanol, which eliminates one oxygen atom and two hydrogen atoms. The formation of ethylene occurs at temperatures between $350{ }^{\circ} \mathrm{C}$ and $500{ }^{\circ} \mathrm{C}$, which promotes the use of adiabatic reactors because they provide suitable temperature sets and low investment costs (Kagyrmanova et al. 2011; Nitzsche et al. 2016). At low temperatures, intermolecular dehydration also produces diethyl ether, which can be sequentially dehydrated to form ethylene. Therefore, controlling these side reactions could reduce the costs associated with the removal of by-products (de Andrade Coutinho et al. 2013).

Ethylene production from lignocellulosic biomass at the industrial level requires processes that attain the theoretical yield of 2 ethylene mol/glucose mol or $0.31 \mathrm{~g} / \mathrm{g}$ by glucose fermentation to ethanol and subsequent acid-catalyzed ethanol dehydration to ethylene. Ideally, $1 \mathrm{~mol}$ of glucose can be converted to $2 \mathrm{~mol}$ of ethylene produced from ethanol, using enzymes for dehydration together with ethanol-producing microorganisms. However, more studies on the equilibrium of the dehydration reaction and the fermentation conditions are required to determine the technical feasibility of this process (Endres 2017; Pardo et al. 2018).

In brief, the process to obtain marketable polymer-grade ethylene involves several stages. First, the concentrated ethanol must be pressurized at $1.14 \mathrm{MPa}$. Next, the feed stream must be preheated using the hot exhaust gas from the adiabatic reactor, after which it is cooled to $84^{\circ} \mathrm{C}$. The water in the gas stream at the top of a rapid cooling tower is then condensed at $1 \mathrm{MPa}$. The solution is cooled to $20{ }^{\circ} \mathrm{C}$, and a fraction of the bottom liquid is recirculated. Next, the dry gas is compressed to $2.7 \mathrm{MPa}$ in a three-stage compressor, removing the condensed water from each stage of the compressor. The $\mathrm{CO}_{2}$ is absorbed in a packed column, washed with $\mathrm{NaOH}$, and the gas is washed with a water spray at the top of the column to remove the $\mathrm{NaOH}$. The remaining water is then extracted in the ethylenerich gas with a molecular sieve. Finally, the gas is cooled to saturation and cryogenic distillation (84 stages and a pressure drop of $0.25 \mathrm{MPa}, 75 \%$ efficiency) to remove the heavier impurities.

The heaviest hydrocarbons are removed in the bottom flow, and the top product is ethylene, with a $99.1 \%$ recovery rate. The $\mathrm{CO}, \mathrm{CH}_{4}$, and $\mathrm{H}_{2}$ are removed with a $75 \%$ efficiency from ethylene in a 20-stage downstream stripper with a $0.25 \mathrm{MPa}$ pressure drop. The bottom product is polymeric ethylene. The overhead compounds are pressurized and partially condensed, while the low molecular weight compounds are vented, and the condensed ethylene is returned to the separator (Morschbacker 2009; Nitzsche et al. 2016).

For the dehydration reaction, catalysts are necessary (Fan et al. 2013). Many laboratories are developing synthesized catalysts to achieve better ethanol conversion and ethylene selectivity rates (Wu and $\mathrm{Wu} 2017$ ). These should soon allow the profitability of large-scale bio-ethylene production (Kagyrmanova et al. 2011) compared to steam cracking plants (Fan et al. 2013). The different catalysts that have been tested and developed to produce bio-ethylene are shown in Table 2. Alumina or alumina in conjunction with metal oxides as promoters, silica, clay, several metal oxides, phosphorus oxides, phosphates, molybdates, sulfuric acid, and zeolites, among others, have been studied as catalysts. Industrially, phosphoric acid and alumina have been used on a smallscale and they have been used to increase the ethylene selectivity (de Andrade Coutinho et al. 2013). 
Table 2. Catalysts Tested for the Ethanol Dehydration Reaction to Produce Ethylene

\begin{tabular}{|c|c|c|c|c|c|}
\hline Catalyst & $\begin{array}{l}\text { Max. Ethylene } \\
\text { Selectivity (\%) }\end{array}$ & $\begin{array}{c}\text { Ethanol } \\
\text { Conversion } \\
(\%) \\
\end{array}$ & $\begin{array}{c}\text { Reaction } \\
\text { Temperature } \\
\left({ }^{\circ} \mathrm{C}\right) \\
\end{array}$ & Stability & Reference \\
\hline $\begin{array}{c}\text { Zeolite HZSM-5 modified } \\
\text { with } 0.5 \%-L a-2 \% \text { P }\end{array}$ & 99.9 & 100 & 240 to 280 & High & $\begin{array}{l}\text { (Hu et al. } \\
2010)\end{array}$ \\
\hline $\mathrm{Si} / \mathrm{Al}$ & 99.0 & 100 & \multirow{2}{*}{500} & High & \multirow{2}{*}{$\begin{array}{c}\text { (Rossetti et al } \\
\text { 2017) }\end{array}$} \\
\hline $\mathrm{Y}-\mathrm{Al}_{2} \mathrm{O}_{3}$ & 80 & 100 & & Stable & \\
\hline HZSM-5 & 98.8 & 99.0 & 250 & \multirow{4}{*}{ High } & \multirow{4}{*}{$\begin{array}{c}\text { (Sheng et al. } \\
\text { 2013) }\end{array}$} \\
\hline HT400 & 98.9 & 99 & 260 & & \\
\hline HT500 & 98.5 & 98.6 & 275 & & \\
\hline HT550 & 98.2 & 94.9 & 290 & & \\
\hline $\begin{array}{l}\text { La-modified HZSM-5 } \\
\text { zeolite }\end{array}$ & 98.5 & 99.5 & 260 & High & $\begin{array}{c}\text { (Ouyang et al. } \\
\text { 2009) }\end{array}$ \\
\hline $\begin{array}{c}\text { Phosphorus (P) modified } \\
\text { H-ZSM-5 }\end{array}$ & 98 & 99 & 450 & High & \begin{tabular}{|c} 
(Ramesh et al. \\
$2010)$ \\
\end{tabular} \\
\hline $\mathrm{Al}_{2} \mathrm{O}_{3}$ & 97.7 & 99.8 & $>400$ & High & $\begin{array}{c}\text { (Tripodi et al. } \\
\text { 2019) }\end{array}$ \\
\hline $\mathrm{Al}_{2} \mathrm{O}_{3}$ & 97 & 99 & 450 & High & $\begin{array}{c}\text { (Kagyrmanova } \\
\text { et al. 2011) }\end{array}$ \\
\hline HZSM-5 zeolite & 90 & 90 & $245-260$ & Stable & $\begin{array}{l}\text { (Moon et al. } \\
\text { 2019) }\end{array}$ \\
\hline \multirow{4}{*}{$\begin{array}{c}\mathrm{Al}_{2} \mathrm{O}_{3} \\
\mathrm{HZSM}-5 \\
\text { SAPO-34 } \\
\text { NiAPSO-34 }\end{array}$} & 82.8 & 90.1 & \multirow{4}{*}{350 to 475} & \multirow{4}{*}{ Stable } & \multirow{4}{*}{$\begin{array}{l}\text { (Zhang et al. } \\
\text { 2008) }\end{array}$} \\
\hline & 93.1 & 97.3 & & & \\
\hline & 86.0 & 93.5 & & & \\
\hline & 92.3 & 96.5 & & & \\
\hline \multirow{2}{*}{ Zeolite ZSM-5 } & 80 & 99 & 400 & \multirow{2}{*}{ Low } & \multirow{2}{*}{$\begin{array}{c}\text { (Wu and } \mathrm{Wu} \\
2017)\end{array}$} \\
\hline & 72 & 42 & 300 & & \\
\hline
\end{tabular}

Kagyrmanova et al. (2011) reported maximal ethylene selectivity when the concentration of ethanol in the feedstock was above $94 \mathrm{wt} \%$ between $370{ }^{\circ} \mathrm{C}$ and $400{ }^{\circ} \mathrm{C}$. Ouyang et al. (2009) achieved a maximum ethylene selectivity of $98.5 \%$ and an ethanol conversion rate of $99.5 \%$, which indicated that higher temperatures favored the dehydration reaction of ethanol and the yield of ethylene.

Alumina is the most commonly used catalyst for the dehydration of bioethanol, as it can withstand temperatures above $450{ }^{\circ} \mathrm{C}$, but it deactivates quickly at temperatures below $300{ }^{\circ} \mathrm{C}$. Zeolites are used to carry out the reaction because they do not require high temperatures, but at low-temperatures coke formation can produce the catalyst deactivation (de Andrade Coutinho et al. 2013). For example, Sheng et al. (2013) reported maximum ethylene selectivity and ethanol conversion rates of $98.8 \%$ and $99 \%$, respectively, when HZSM-5 was used as a catalyst at a temperature of $250{ }^{\circ} \mathrm{C}$.

The effluents contain a high amount of water from the dehydration reaction, as well as ethanol feedstock and heat-carrying fluid. Water can be separated in a quench tower, and the residual ethanol and water-soluble oxygenates can be re-heated and distilled. The residual ethanol and diethyl ether (low water solubility) can be recovered and recycled to the feedstock, while the $\mathrm{C}_{2} \mathrm{H}_{4} \mathrm{O}$ can be burned in the furnace. The gas from the top of the quench tower primarily contains ethylene ( $90 \%$ to $99.5 \%$ ), hydrocarbons, $\mathrm{H}_{2}, \mathrm{CO}, \mathrm{CO}_{2}$, and oxygenates. The ethylene can be washed with cool water in a second tower removes the oxygenates, and caustic washing can remove $\mathrm{CO}_{2}$ and acids (de Andrade Coutinho et al. 2013). 


\section{CONSIDERATIONS IN THE USE OF LIGNOCELLULOSIC BIOMASS FOR ETHYLENE PRODUCTION}

\section{Technical Considerations}

In a biorefinery platform for ethylene production from biomass, either by biochemical or thermochemical pathways (Alonso-Fariñas et al. 2018), the high energy consumption could lead to high production costs. Several ethylene production processes have been developed and analyzed. Hackl et al. (2011) found that when one refinery was used for the bio-ethylene production process, the heat utility demand of the ethanol and the ethylene plants decreased from $131 \mathrm{MW}$ to less than $80 \mathrm{MW}$. In a combined biorefinery, the flue gas can be integrated with the ethanol dehydration reactors, which will further reduce the utility demands (Hackl et al. 2011).

In the biochemical process, the pretreatment and ethanol recovery stages consume a large amount of energy (Hackl et al. 2011; Nitzsche et al. 2016). The complexity of wood as raw material directly affects the integration mechanism (Mendieta et al. 2019) and the pretreatment cost (Rosales-Calderon and Arantes 2019). Energy integration strategies could be applied in these processes, with theoretical savings for heat demand of $31.5 \%$ (15.1 MW) and cooling demand of 39.5\% (13.8 MW) (Nitzsche et al. 2016; Becerra et al. 2017). Generally, the production of ethanol requires a large amount of energy. Among the strategies developed to make it cost-effective (Ferreira et al. 2018; Ayodele et al. 2020), the most important are heat, energy, and mass integration (Cardona and Sánchez 2007; Clauser et al. 2021).

Among the different alternatives mentioned to integration, the most promising replaces the improvement of the individual sectors with a systemic approach, with a full scope of the process. In this way, it is possible to control the effect of the optimization proposed in each of the stages (Hackl and Harvey 2016; Valderrama et al. 2020). In this sense, it is possible to take advantage of the high heat content in the different stages, as the condensation in the ethanol purification at the output of ethylene reactors. Besides, the heat available in the cooling of the hydrolysis and fermentation processes can be leveraged in the ethanol production process, for example, in the pretreatment stage (Alonso-Fariñas et al. 2018). Nowadays, the facilities that use cogeneration and have residual heat can sell the excess. However, the profit of heat exchange reduces their advantages when ethanol production and dehydration to bio-ethylene processes are located in different locations (Hackl and Harvey 2016).

Some of the improvements obtained through process integration are summarized in Table 3. Moreover, the high investment costs for development at the industrial scale should be taken into consideration. There are complicated factors to consider in the decisionmaking process, such as the raw material, the pretreatment methods, the production costs, the production scale, and the yield, among others (Kang et al. 2014a; Brown 2015; de Assis et al. 2017; Meneses 2018). In order to attain competitive production costs, it is necessary to improve other key factors such as the development of new low-cost conversion strategies. Such strategies may include reducing the consumption of enzymes, reagents, and water, among others, in addition to new strategic policies for bio-based products. The production of derivatives and new products must be developed for the emerging bio-based markets (Mohsenzadeh et al. 2017; Tripodi et al. 2019). Biopolyethylene, which can be replaced in various uses by degradable bioplastics, is still essential in some medical and industrial applications. So, the processing of this classical derivative, and also of bio-PET, must also be improved.

Mendieta et al. (2021). "Wood wastes to bio-ethylene," BioResources 16(2), 4411-4437. 4420 
Table 3. Integration Strategies for Ethanol and Ethylene Production

\begin{tabular}{|c|c|c|c|}
\hline Feedstock & Strategy & Improvement & Ref \\
\hline Sugarcane & $\mathrm{El}$ & $\begin{array}{c}\text { Energy reduction of } 50 \% \text { compared with no } \\
\text { energy integration. }\end{array}$ & $\begin{array}{l}\text { (Oliveira et } \\
\text { al. 2016) }\end{array}$ \\
\hline Sugarcane & $\mathrm{El}$ & $\begin{array}{l}\text { With the integrated heat exchanger networks } \\
\text { (HEN) it is possible to reach more than } 70 \% \text { of } \\
\text { process steam reduction with energy } \\
\text { integration. }\end{array}$ & $\begin{array}{l}\text { (Oliveira et } \\
\text { al. 2018) }\end{array}$ \\
\hline Beechwood & $\mathrm{El}$ & $\begin{array}{c}\text { The demand for total energy was reduced by } \\
\text { more than } 32 \% \text {. }\end{array}$ & $\begin{array}{l}\text { (Nitzsche et } \\
\text { al. 2016) }\end{array}$ \\
\hline $\begin{array}{c}\text { Molasses and } \\
\text { sugarcane } \\
\text { bagasse }\end{array}$ & El, MI & $\begin{array}{l}53 \% \text { reduction of heat exchange units and } \\
19.25 \% \text { reduction of the cost of industrial } \\
\text { cooling services. } \\
\begin{array}{l}16.53 \% \text { reduction of the process freshwater } \\
\text { consumption. }\end{array} \\
\end{array}$ & $\begin{array}{l}\text { (Valderrama } \\
\text { et al. 2020) }\end{array}$ \\
\hline $\begin{array}{l}\text { Sugarcane } \\
\text { bagasse }\end{array}$ & El, Ml & $\begin{array}{c}\text { Potential reduction in steam consumption by } \\
\text { almost } 35 \% \text {. }\end{array}$ & $\begin{array}{l}\text { (Dias et al. } \\
\text { 2011) }\end{array}$ \\
\hline Corn stover & $\mathrm{El}^{*}$ & Up to $47.6 \%$ savings of the total annual costs. & $\begin{array}{c}\text { (Nhien et al. } \\
\text { 2017) }\end{array}$ \\
\hline
\end{tabular}

El: Energy integration; MI: Mass integration. *Energy integration and intensification.

While the development of a biorefinery plant presents some challenges, it does offer some considerable advantages (Fig. 3).

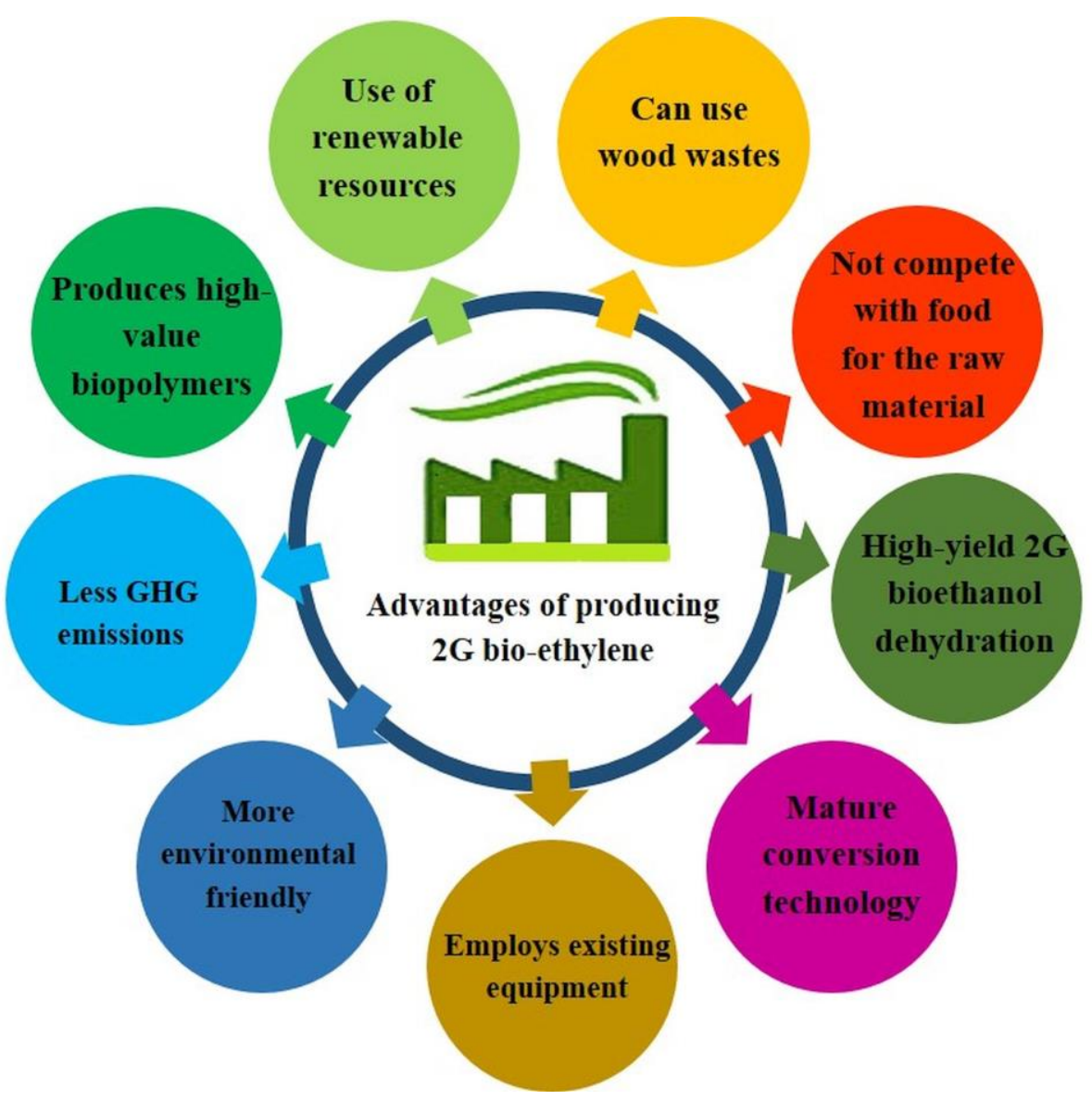

Fig. 3. The advantages of converting wood waste product to bio-ethylene 


\section{Economic Considerations}

The reported selling price of $1 \mathrm{G}$ bio-ethylene is approximately $\$ 1,100$ to $\$ 1,500$ USD/t (Budzinski and Nitzsche 2016; Nitzsche et al. 2016; Alonso-Fariñas et al. 2018; Jiang et al. 2019), but in some cases it may reach higher than $\$ 2,000 \mathrm{USD} / \mathrm{t}$ (Taylor et al. 2015). According to recent investment information, the capital costs for bio-ethylene production, depending on the process, could range from $\$ 460 \mathrm{USD} / \mathrm{t}$ (Becerra et al. 2017), between \$1,100 and \$1,400 USD/t (Broeren 2013), \$3,880 USD/t (Nitzsche et al. 2016), and \$5,750 USD/t of ethylene per year (Budzinski and Nitzsche 2016). Some of the production costs are presented in Table 4.

Table 4. Ethylene Production Costs as Reported by Several Studies

\begin{tabular}{|c|c|c|c|c|c|}
\hline Raw Material & $\begin{array}{c}\text { Capacity } \\
\text { (ton of ethylene/ } \\
\text { year) }\end{array}$ & Year & $\begin{array}{c}\text { Production } \\
\text { Cost } \\
\text { (USD/t) }\end{array}$ & Country & Ref \\
\hline Beech wood & $400,000^{a}$ & 2016 & $1,349^{b}$ & Germany & $\begin{array}{c}\text { (Nitzsche et al. } \\
\text { 2016) }\end{array}$ \\
\hline Corn $^{b}$ & - & 2009 & 2,060 & USA & $\begin{array}{c}\text { (Broeren } \\
2013)\end{array}$ \\
\hline Sugarcane & - & 2009 & 1,190 & Brazil & $\begin{array}{c}\text { (Broeren } \\
\text { 2013) }\end{array}$ \\
\hline Sugarcane & - & 2009 & 1,220 & India & $\begin{array}{c}\text { (Broeren } \\
2013)\end{array}$ \\
\hline Sugar beets & - & 2009 & 2,570 & $\begin{array}{l}\text { Europe } \\
\text { Union }\end{array}$ & $\begin{array}{c}\text { (Broeren } \\
2013) \\
\end{array}$ \\
\hline Sweet sorghum & - & 2009 & 1,650 & China & $\begin{array}{l}\text { (Broeren } \\
2013)\end{array}$ \\
\hline $\begin{array}{c}\text { Sugarcane } \\
\text { bagasse }\end{array}$ & 500,000 & 2019 & $\begin{array}{c}1,006 \text { to } \\
1,436\end{array}$ & Brazil & $\begin{array}{c}\text { (Oliveira et al. } \\
\text { 2019) }\end{array}$ \\
\hline $\begin{array}{c}\text { Spruce - Salix - } \\
\text { Corn stover }\end{array}$ & 200,000 & 2011 & $\begin{array}{c}1,012 \text { to } \\
1,084^{\circ} \\
\end{array}$ & Sweden & $\begin{array}{c}\text { (Hackl et al. } \\
\text { 2011) }\end{array}$ \\
\hline Sugarcane & $1,000,000$ & 2012 & 1,347 & Brazil & $\begin{array}{l}\text { (Cameron et } \\
\text { al. 2012) }\end{array}$ \\
\hline Corn & 9.9 to $38.9^{d}$ & 2013 & $\begin{array}{c}1,724 \text { to } \\
1,762^{\mathrm{c}} \\
\end{array}$ & $\begin{array}{l}\text { Europe } \\
\text { Union }\end{array}$ & $\begin{array}{c}\text { (Haro et al. } \\
\text { 2013) }\end{array}$ \\
\hline Biomass & 9.9 to $38.9^{d}$ & 2013 & $\begin{array}{c}1,219 \text { to } \\
1,182^{\mathrm{c}}\end{array}$ & USA & $\begin{array}{c}\text { (Haro et al. } \\
2013)\end{array}$ \\
\hline Sugarcane & 9.9 to $38.9^{d}$ & 2013 & $\begin{array}{c}1,053 \text { to } \\
1,016^{c}\end{array}$ & Brazil & $\begin{array}{c}\text { (Haro et al. } \\
2013)\end{array}$ \\
\hline
\end{tabular}

${ }^{a}$ Raw material per year. ${ }^{b}$ Minimum selling price in $€$. Values in $€ .{ }^{d} / h$.

The prices and production costs of bio-ethylene are similar to those of oil-derived ethylene (Nitzsche et al. 2016; Santagata et al. 2020). However, the market price of bioethylene derivates, such as polymers, is slightly higher than the market price of oil-derived ones (Taylor et al. 2015). Some researchers have reported a 30\% to $60 \%$ premium in the price of bio-PE (Taylor et al. 2015; Nitzsche et al. 2016). Similarly, the price of bio-PET is not competitive with the usual price of PET (Taylor et al. 2015). However, the biorefinery concept looks very promising when considering the willingness of consumers to pay a higher price for biopolymers and bio-ethylene (Nitzsche et al. 2016).

Sensitivity assessments developed for bio-ethylene production using sugarcane and beech wood as raw materials showed a strong dependence on the price of the raw material (Nitzsche et al. 2016; Oliveira et al. 2019) and the selling prices of the products (Nitzsche 
et al. 2016). In these works, the cost of the raw material was important (more than $\$ 100$ $\mathrm{USD} / \mathrm{t}$ in some cases). However, in developing countries, the costs of the feedstock and labor are lower than in developed countries, so bio-ethylene production may be an attractive alternative to add value to lignocellulosic wastes. For example, the raw material may comprise $60 \%$ to $75 \%$ of the production costs depending mainly on the final product (biomass or ethanol) and the geographic region, but in regions where the feedstock and labor are cheaper, like Brazil, India, and Argentina, the production costs could be reduced (Mohsenzadeh et al. 2017).

Currently, mills like Braskem in Brazil (Broeren 2013; Oliveira et al. 2019), India Glycols Limited in India (Global Market Insights, 2016), and Greencol Taiwan Corporation in Taiwan (Chemicals-Technology 2020), produce 1G ethylene from sugarcane and molasses, with annual capacities between 100 and $200 \mathrm{kt}$. There are also projects in a developing stage like Dow/Mitsui in Brazil from sugarcane (with a project capacity of $300 \mathrm{kt} / \mathrm{year}$ ) (Moser 2013). There are reports of several plants in China with annual capacities between $9 \mathrm{kt}$ and $80 \mathrm{kt}$, but their status is unknown (Broeren 2013).

\section{Environmental Considerations}

Compared to fossil-fuel based ethylene, the production of bio-ethylene has great potential to reduce environmental impacts. However, new developments in the conversion and recovery processes are necessary to make commercial-scale production of bio-ethylene feasible. Some global progress has been made to make this a reality. In 2015, 17 sustainable development goals were listed by world leaders that sought to delay climate change, including improvements in sustainable energy generation, industry and innovation, responsible consumption, and sustainable use of biodiversity (Organización de las Naciones Unidas 2015; Mestre 2018). All these concepts align with the biorefinery schemes adapted to the circular bioeconomy (Näyhä 2012; Cristóbal et al. 2016). However, the bioeconomy amounts to only $11 \%$ of the economy of the European Union and $5 \%$ of that of the USA (Kuosmanen et al. 2020; The National Academies of Science, Engineering, and Medicine 2020).

There are few studies on the life cycle assessment (LCA) of chemicals derived from biomass (Alonso-Fariñas et al. 2018). For bioethanol production, base-product of $2 \mathrm{G}$ bioethylene, studies have shown a clear reduction in GHG emissions and ozone layer depletion (Morales et al. 2015).

Compared to bio-ethylene, fossil-based ethylene production greatly contributes to global warming and photochemical ozone creation (Liptow et al. 2015). Carbon dioxide emissions can be reduced by approximately 2.5 tons per ton of produced bio-ethylene if fossil-fuel based chemicals are replaced by biobased ones (de Jong et al. 2012a).

A LCA compared thermochemical and biochemical processes for bio-ethylene production from sugar beets, considering 11 potential impacts (Liptow et al. 2015). The LCA showed that the gasification pathway has a lower impact than the fermentation route. The bio-chemical option had a lower impact on human toxicity, freshwater aquatic ecotoxicity, and terrestrial ecotoxicity potential than the thermo-chemical route. For the remaining eight impacts, the thermochemical option was more sustainable (Alonso-Fariñas et al. 2018). Compared with fossil-fuel based PE, bio-PE can reduce environmental emissions (Ita-Nagy et al. 2020). Sugarcane-based bio-PE can reduce GHG emissions by more than 50\% (Taylor et al. 2015). However, biomass conversion by both the fermentation and gasification processes should be further analyzed. Various GHG emission savings were reported for the different derivatives of bio-ethylene.

Mendieta et al. (2021). "Wood wastes to bio-ethylene," BioResources 16(2), 4411-4437. 4423 
Achieving the commercial-scale development of biorefinery processes requires the involvement of private entities (producers and industry), state organizations (such as universities), and society (Wierny et al. 2015; Nguyen et al. 2020). Additionally, the laws that guarantee the regulatory framework must be approved (Mestre 2018), and the establishment of the LCA of both fossil-fuel based and bio-based products and materials must be encouraged (Nguyen et al. 2020).

\section{Availability of Raw Materials}

The productive characteristics of Latin America determine the development of biorefineries (Wierny et al. 2015). In 2017, the bioeconomy sector accounted for approximately $16 \%$ of Argentina's gross domestic product (GDP) (Coremberg 2018). To increase the impact of bio-based products in the global economy, key factors such as government policies and intersectoral cooperation, among others, must be promoted in the country (Nizami et al. 2017).

In Argentina, approximately 50\% of the wood from sawmill production, pruning, thinning, and logging is discarded as waste. If an industrial strategy is developed to utilize this wood waste, it can be capitalized for other uses (Uasuf and Hilber 2012; de Assis et al. 2017; Clauser 2019; Körte et al. 2019). The forestry industry is the primary economic activity in the northeast region of Argentina (Area and Park 2017). Sawmills and lumber mills generate approximately 2.35 million dry tons of wood waste per year, most of which is slash pine and loblolly pine sawdust (Laharrague 2018). In the northeast region of Argentina, forest waste (without urban pruning) amounts to approximately 16 million tons per year (Peirano et al. 2019).

Table 5. Recent Studies Carried out in Argentina Oriented to Obtain 2G Bioethanol

\begin{tabular}{|c|c|c|c|c|c|}
\hline $\begin{array}{c}\text { Raw } \\
\text { Materials }\end{array}$ & Province & Process & Conditions & Scale & References \\
\hline $\begin{array}{c}\text { Pine } \\
\text { sawdust }\end{array}$ & Misiones & $\begin{array}{c}\text { Organosolv } \\
\text { pretreatment } \\
\text { SSF Strategy }\end{array}$ & $\begin{array}{c}\mathrm{EtOH} / \mathrm{NaOH} ; 1 \mathrm{~h}, \\
170^{\circ} \mathrm{C} \\
\text { T. reesei }(20 \mathrm{FPU} / \mathrm{g} \\
\text { glucans); } 48 \mathrm{~h}, 50^{\circ} \mathrm{C} \\
\text { S. cerevisiae; } 72 \mathrm{~h} \text {, } \\
30^{\circ} \mathrm{C}\end{array}$ & $\begin{array}{c}\text { Reactor of } \\
200 \mathrm{~mL}, 100 \\
\mathrm{~mL} \text { working } \\
\text { volume }\end{array}$ & $\begin{array}{c}\text { (Kruyeniski } \\
2017)\end{array}$ \\
\hline $\begin{array}{c}\text { Pine } \\
\text { sawdust }\end{array}$ & Misiones & $\begin{array}{l}\text { SHF/SSF } \\
\text { Strategy }\end{array}$ & $\begin{array}{c}\text { Cellic } \circledast \text { Ctec2 } \\
\text { S. cerevisiae, } \\
72 \mathrm{~h}, 37^{\circ} \mathrm{C}\end{array}$ & $\begin{array}{c}250 \mathrm{~mL} \\
\text { Erlenmeyer } \\
\text { flasks, } 100 \\
\text { mL working } \\
\text { volume } \\
\end{array}$ & $\begin{array}{c}\text { (Mendieta } \\
\text { 2020) }\end{array}$ \\
\hline $\begin{array}{c}\text { Pine } \\
\text { sawdust }\end{array}$ & Misiones & $\begin{array}{l}\text { Pretreatment } \\
\text { (Acid and } \\
\text { alkaline) } \\
\\
\text { Enzymatic } \\
\text { hydrolysis }\end{array}$ & $\begin{array}{c}\mathrm{H}_{2} \mathrm{SO}_{4 ;} 1 \mathrm{~h}, 121^{\circ} \mathrm{C} \\
\mathrm{NaOH} ; 1 \mathrm{~h}, 121^{\circ} \mathrm{C} \\
\text { Celluclast巴 } 1.5 \mathrm{~L} \\
\text { (Sigma) } \\
96 \mathrm{~h}, 50^{\circ} \mathrm{C}\end{array}$ & $\begin{array}{l}100 \mathrm{~mL} \\
\text { Erlenmeyer } \\
\text { flasks, } 50 \\
\text { mL working } \\
\text { volume }\end{array}$ & $\begin{array}{l}\text { (Rodríguez } \\
\text { et al. 2017) }\end{array}$ \\
\hline Rice husks & Chaco & $\begin{array}{c}\text { Pretreatment } \\
\text { Enzymatic } \\
\end{array}$ & $\begin{array}{c}\mathrm{NaOH} ; 1 \mathrm{~h}, 121^{\circ} \mathrm{C} \\
\text { Ctec2 (30 FPU/g } \\
\text { glucans, }\end{array}$ & $\begin{array}{c}250 \mathrm{~mL} \\
\text { Erlenmeyer } \\
\text { flasks, } 200 \\
\mathrm{~mL} \text { working }\end{array}$ & $\begin{array}{l}\text { (Arismendy } \\
\text { et al. 2019) }\end{array}$ \\
\hline
\end{tabular}

Mendieta et al. (2021). "Wood wastes to bio-ethylene," BioResources 16(2), 4411-4437. 4424 


\begin{tabular}{|c|c|c|c|c|c|}
\hline & & $\begin{array}{l}\text { hydrolysis and } \\
\text { fermentation }\end{array}$ & $\begin{array}{l}\text { S. Cerevisiae, } \\
72 \mathrm{~h}, 37^{\circ} \mathrm{C}\end{array}$ & volume & \\
\hline Rice husks & Chaco & $\begin{array}{c}\text { Pretreatment } \\
\text { SHF/SSF } \\
\text { Strategy }\end{array}$ & $\begin{array}{l}\mathrm{NaOH} ; 1 \mathrm{~h}, 121^{\circ} \mathrm{C} \\
\text { Ctec2 (30 FPU/g } \\
\text { glucans), } \\
\text { S. cerevisiae, } \\
72 \mathrm{~h}, 37^{\circ} \mathrm{C}\end{array}$ & $\begin{array}{c}250 \mathrm{~mL} \\
\text { Erlenmeyer } \\
\text { flasks, } 100 \\
\text { mL working } \\
\text { volume }\end{array}$ & $\begin{array}{l}\text { (Arismendy } \\
\text { et al. 2020) }\end{array}$ \\
\hline $\begin{array}{c}\text { White } \\
\text { grape marc }\end{array}$ & Mendoza & $\begin{array}{c}\text { Acid } \\
\text { pretreatment } \\
\text { Saccharification } \\
\text { and fermentation }\end{array}$ & $\begin{array}{l}\mathrm{H}_{2} \mathrm{SO}_{4} \text { (diluted); } 1 \mathrm{~h}, \\
97{ }^{\circ} \mathrm{C} \\
\text { Ultrazym Premium } \\
\text { DX enzyme; } 20 \mathrm{~h}, 45 \\
{ }^{\circ} \mathrm{C} \\
\text { S. cerevisiae; } 20 \mathrm{~h}, \\
28^{\circ} \mathrm{C}\end{array}$ & $\begin{array}{l}500 \mathrm{~mL} \\
\text { Erlenmeyer } \\
\text { flasks, } 350 \\
\text { mL working } \\
\text { volume }\end{array}$ & (Díaz 2018) \\
\hline $\begin{array}{l}\text { Sawdust } \\
\text { black carob }\end{array}$ & Chaco & $\begin{array}{l}\text { Organosolv } \\
\text { pretreatment } \\
\text { Acid hydrolysis }\end{array}$ & $\begin{array}{c}\mathrm{NaOH}-\mathrm{EtOH}-\mathrm{H}_{2} \mathrm{O} ; 1 \\
\text { h, } 121^{\circ} \mathrm{C} \\
\mathrm{H}_{2} \mathrm{SO}_{4} ; 1 \mathrm{~h}, 121^{\circ} \mathrm{C}\end{array}$ & $\begin{array}{l}\text { Reactor AISI } \\
316,180 \mathrm{~mL} \\
\text { working } \\
\text { volume }\end{array}$ & $\begin{array}{l}\text { (Dagnino et } \\
\text { al. 2018) }\end{array}$ \\
\hline Sugarcane & Tucumán & $\begin{array}{c}\text { Alkaline } \\
\text { pretreatment } \\
\text { SSF Strategy }\end{array}$ & $\begin{array}{c}\mathrm{NaOH} ; 1 \mathrm{~h}, 121^{\circ} \mathrm{C} \\
\text { Ctec2 and Cellic } \AA \\
\text { Htec2, S. cerevisiae } \\
72 \mathrm{~h}, 35^{\circ} \mathrm{C}\end{array}$ & $\begin{array}{c}100 \mathrm{~mL} \\
\text { Erlenmeyer } \\
\text { flasks, } 30 \\
\text { mL working } \\
\text { volume }\end{array}$ & $\begin{array}{l}\text { (Manfredi et } \\
\text { al. 2018) }\end{array}$ \\
\hline $\begin{array}{c}\text { Eucalyptus } \\
\text { globulus }\end{array}$ & Santa Fe & $\begin{array}{l}\text { Steam } \\
\text { Explosion, } \\
\text { Dilute sulfuric } \\
\text { acid }\end{array}$ & $\begin{array}{c}\mathrm{H}_{2} \mathrm{SO}_{4} ; 1 \mathrm{~h}, 173 \text { and } \\
216{ }^{\circ} \mathrm{C} \\
\mathrm{H}_{2} \mathrm{SO}_{4} ; 1 \mathrm{~h}, 120 \text { and } \\
140{ }^{\circ} \mathrm{C}\end{array}$ & $\begin{array}{c}\text { Not } \\
\text { specified }\end{array}$ & $\begin{array}{l}\text { (Vargas } \\
\text { and } \\
\text { Vecchietti } \\
\text { 2018) }\end{array}$ \\
\hline $\begin{array}{l}\text { Melon } \\
\text { residues }\end{array}$ & San Juan & $\begin{array}{c}\text { Acid } \\
\text { pretreatment } \\
\text { Enzymatic } \\
\text { hydrolysis } \\
\text { Fermentation }\end{array}$ & $\begin{array}{l}\mathrm{H}_{2} \mathrm{SO}_{4} \text { (diluted); } 1 \mathrm{~h} \text {, } \\
55{ }^{\circ} \mathrm{C} \\
\text { T. reesei }(20 \mathrm{FPU} / \mathrm{g} \\
\text { pulp) ATCC26921; } \\
24 \mathrm{~h}, 45{ }^{\circ} \mathrm{C} \\
\text { S. cerevisiae; } 72 \mathrm{~h} \text {, } \\
35{ }^{\circ} \mathrm{C}\end{array}$ & $\begin{array}{c}1000 \mathrm{~mL} \\
\text { Erlenmeyer } \\
\text { flasks, } 700 \\
\text { mL working } \\
\text { volume }\end{array}$ & $\begin{array}{l}\text { (Montoro et } \\
\text { al. 2020) }\end{array}$ \\
\hline $\begin{array}{l}\text { Wheat } \\
\text { straw and } \\
\text { barley } \\
\text { straw }\end{array}$ & $\begin{array}{l}\text { Buenos } \\
\text { Aires }\end{array}$ & SSF Strategy & $\begin{array}{c}\text { Ctec2 (20 FPU/g } \\
\text { pulp) } \\
\text { S. cerevisiae } \\
72 \mathrm{~h}, 30^{\circ} \mathrm{C}\end{array}$ & $\begin{array}{l}100 \mathrm{~mL} \\
\text { Erlenmeyer } \\
\quad \text { flasks }\end{array}$ & $\begin{array}{c}\text { (Campos } \\
2018)\end{array}$ \\
\hline
\end{tabular}

Typically, these wood residues are used in boilers and, in the case of pulp and paper mills, are used for steam generation and electrical energy production (Arauco 2020). Some companies produce market chips and pellets destined for Brazil and Uruguay (GP Energy 2020). Various wood residues have different low-value uses in each province. For example, bags of pet products from wood residues, without compacting (Noticias 2010; PinoPack 2020), filler for bricks, firewood (Petri et al. 2016), and landfills (Petri et al. 2018), are 
sold in Misiones, Formosa, and Chaco, respectively. No references for obtaining bioethylene from biomass in Argentina were found. Several studies were conducted to obtain $2 \mathrm{G}$ ethanol in conditions that can be used to produce bio-ethylene (Table 5).

Among the parameters requiring optimization to increase yields, the time of the fermentation stage is a key factor for the subsequent processing steps. For example, (Arismendy et al. 2019) obtained the highest production of hydrolyzed sugars at $13 \mathrm{~h}$ in the enzymatic hydrolysis stage, (Díaz 2018) at $20 \mathrm{~h}$, and (Montoro et al. 2020) at $24 \mathrm{~h}$. The chosen pretreatment is another key factor. For example, the alkaline pretreatments are the most used because they favor the subsequent saccharification of cellulose. Temperature is also an important factor that must be taken into account so that the microorganisms used can carry out their work; for example (Mendieta 2020) and (Pabón et al. 2020) used the SSF strategy employing a temperature of $37^{\circ} \mathrm{C}$, being a temperature higher than that used in traditional fermentations. However, Manfredi et al. (2018) and Campos (2018) used temperatures of $35^{\circ} \mathrm{C}$ and $30^{\circ} \mathrm{C}$, respectively.

Numerous studies state the relevance of using lignocellulosic residues available in the region. Even if potential uses are identified, they are not currently developed.

\section{CONCLUDING STATEMENTS}

1. This review has shown that bio-ethylene production from $2 \mathrm{G}$ ethanol could have the potential to compete with fossil-fuel-based ethylene when some stages of the whole process are optimized.

2. Biopolyethylene production is the more classical bio-ethylene market, but other significant markets are the control of the ripening of fruit, and the development of the crop growth in agriculture. Biopolyethylene also can be considered for the production of specialty glass for the automotive industry, as an anesthetic in medical applications, as a refrigerant, and as oxy-fuel gas in metal works.

3. The production of bio-ethylene from $2 \mathrm{G}$ ethanol is an attractive alternative for regions with low-cost raw materials, such as the northeast region of Argentina.

4. Different mass and energy integration strategies could be employed to substantially reduce production costs.

5. The optimization required to obtain competitive costs includes reducing the consumption of enzymes, reagents, energy, and water, finding more efficient catalysts and purification techniques, and developing new strategic policies for bio-based products, among others.

6. The production of bio-ethylene can reduce environmental concerns such as GHG emissions and the depletion of fossil-fuels. Therefore, more research and development in the conversion and recovery processes for bio-ethylene production are necessary.

\section{ACKNOWLEDGMENTS}

The authors would like to thank the National Scientific and Technical Research Council (CONICET) and the National University of Misiones (UNaM).

Mendieta et al. (2021). "Wood wastes to bio-ethylene," BioResources 16(2), 4411-4437. 4426 


\section{REFERENCES CITED}

Adekunle, A., Orsat, V., and Raghavan, V. (2016). "Lignocellulosic bioethanol: A review and design conceptualization study of production from cassava peels," Renewable and Sustainable Energy Reviews 64, 518-530. DOI: 10.1016/j.rser.2016.06.064

Almenares-Verdecía, J. M., Ngoma-Presline, F., and Serrat, M. (2008). "General technological aspects for the conversion to ethanol from lignocellulosic biomass," Tecnología Química 28(3), 63-70.

Alonso-Fariñas, B., Gallego-Schimd, A., Haro, P., and Azapagic, A. (2018). "Environmental assessment of thermo-chemical processes for bio-ethylene production in comparison with bio-chemical and fossil-based ethylene," Journal of Cleaner Production 202, 817-829. DOI: 10.1016/j.jclepro.2018.08.147

Alvarez-Castillo, A., Salgado-Delgado, R., Garcia-Hernández, E., DomínguezDomínguez, M. M., Grandandos-Baeza, J. M., Aguirre-Cruz, A., Carmona-García, R., Morales-Cepeda, A., Herrara-Franco, P. J., Licea-Claveríe, A., et al. (2012). "Aprovechamiento integral de los materiales lignocelulósicosu," Revista Iberoamericana de Polímeros 13(4), 140-150.

Araque, E., Parra, C., Freer, J., Contreras, D., Rodríguez, J., Mendonça, R., and Baeza, J. (2008). "Evaluation of organosolv pretreatment for the conversion of Pinus radiata D. Don to ethanol," Enzyme and Microbial Technology 43(2), 214-219. DOI: 10.1016/j.enzmictec.2007.08.006

Arauco. (2020). "arauco Argentina S.A.," (https://www.arauco.cl/argentina/), Accessed 02 dec 2020.

Area, M. C., and Park, S. W. (2017). "Bio-productos y bio-materiales a partir de la biorrefinería de residuos agro y forestoindustriales," in: Panorama de la Industria de Celulosa y Papel y Materiales Lignocelulósicos 2016, M. C. Area and S. W. Park (eds.), National University of Misiones, Posadas, Argentina, pp. 120-151.

Area, M. C., and Vallejos. (2012). Biorrefinería a partir de residuos lignocelulósicos. Conversión de residuos a productos de alto valor [Biorefinery from Lignocellulosic Waste: Conversion of Waste to High Value Products], Editorial Académica Española, Riga, Latvia.

Arismendy, A. M., Felissia, F. E., Mendieta, C., Chamorro, E. R., and Area, C. M. (2020). "Improvement of bioethanol production from rice husks," Journal Cellulose Chemistry and Tchnology 54 (7-8), 689-698. DOI:

10.35812/CelluloseChemTechnol.2020.54.68

Arismendy, A. M., Retrepo, A. F. V., Alcaraz, W., Chamorro, E. R., and Area, M. C. (2019). "Optimización de la hidrólisis enzimática de la cascarilla de arroz [Optimization of the enzymatic hydrolysis of rice husk]," Repositorio Español de Ciencia y Tecnología 32, 64-70.

Arismendy, A. M., Sequeira, M. J., Felissia, F. E., Area, C. M., and Chamorro, E. R. (2018). "Evaluación de cepas fermentativas en la hidrólisis y fermentación simultáneas (SSF) de cascarilla de arroz para la producción de bioetanol [Evaluation of fermentative strains in the simultaneous hydrolysis and fermentation (SSF) of rice husk for the production of Bioethanol]," Revista Tecnología y Ciencia (30), 357-363. Ayodele, B. V., Alsaffar, M. A., and Mustapa, S. I. (2020). "An overview of integration opportunities for sustainable bioethanol production from first- and second-generation sugar-based feedstocks," Journal of Cleaner Production 245, 118857. DOI: 10.1016/j.jclepro.2019.118857 
Azhar, S. H. M., Abdulla, R., Jambo, S. A., Marbawi, H., Gansau, J. A., Faik, A. A. M., and Rodrigues, K. F. (2017). "Yeasts in sustainable bioethanol production: A review," Biochemistry and Biophysics Reports 10, 52-61. DOI: 10.1016/j.bbrep.2017.03.003

Balat, M. (2011). "Production of bioethanol from lignocellulosic materials via the biochemical pathway: A review," Energy Conversion and Management 52(2), 858875. DOI: 10.1016/j.enconman.2010.08.013

Becerra, J., Figueredo, M., and Cobo, M. (2017). "Thermodynamic and economic assessment of the production of light olefins from bioethanol," Journal of Environmental Chemical Engineering 5(2), 1554-1564. DOI: 10.1016/j.jece.2017.02.035

Brodin, M., Vallejos, M., Opedal, M. T., Area, M. C., and Chinga-Carrasco, G. (2017). "Lignocellulosics as sustainable resources for production of bioplastics - A review," Journal of Cleaner Production 162, 646-664. DOI: 10.1016/j.jclepro.2017.05.209

Broeren, M. (2013). Production of Bio-ethylene, Energy Technology Systems Analysis Program (ETSAP).

Brown, T. R. (2015). "A techno-economic review of thermochemical cellulosic biofuel pathways," Bioresource Technology 178, 166-176. DOI: 10.1016/j.biortech.2014.09.053

Budzinski, M., and Nitzsche, R. (2016). "Comparative economic and environmental assessment of four beech wood based biorefinery concepts," Bioresource Technology 216, 613-621. DOI: 10.1016/j.biortech.2016.05.111

Cameron, G., Le, L., Levine, J., and Nagulapalli, N. (2012). "Process design for the production of ethylene from ethanol," University of Pennsylvania Senior Design Report 39, 1-144.

Campos, E. (2018). Optimización de la Sacaracrificación de Biomasas Lignocelulósicas, Instituto Nacional de Tecnología Agropecuaria, Buenos Aires, Argentina, (https://inta.gob.ar/documentos/optimizacion-de-la-sacarificacion-de-biomasaslignocelulosicas), Accessed 03 December 2020.

Cardona Alzate, C. A., and Sánchez Toro, O. J. (2006). "Energy consumption analysis of integrated flowsheet for production of fuel ethanol from lignocellulosic biomass," Energy 13, 2447-2459. DOI: 10.1016/j.energy.2005.10.020

Cardona, C. A., and Sánchez, Ó. J. (2007). "Fuel ethanol production: Process design trends and integration opportunities," Bioresource Technology 98(12), 2415-2457. DOI: $10.1016 /$ j.biortech.2007.01.002

Chemicals-Technology. (2013). "Greencol Taiwan Corporation Bio-MEG Plant, Taiwan.”, (https://www.chemicals-technology.com/projects/greencolbiomegplant/), Accesed: 27 nov 2020.

Cheng, N., Koda, K., Tamai, Y., Yamamoto, Y., Takasuka, T. E., and Uraki, Y. (2017). "Optimization of simultaneous saccharification and fermentation conditions with amphipathic lignin derivatives for concentrated bioethanol production," Bioresource Technology 232, 126-132. DOI: 10.1016/j.biortech.2017.02.018

Chieregato, A., Ochoa, J. V., and Cavani, F. (2016). “Olefins from Biomass," in: Chemicals and Fuels from Bio-Based Building Blocks, F. Cavani, S. Albonetti, F. Basile, and A. Gandini (eds.), Wiley-VCH, Weinheim, Germany, pp. 1-32.

Clauser, N. M. (2019). Estudio Tecnico-Económico de la Biorrefinería de los Residuos de Industrialización Primaria de la Madera y Agroindustriales [Technical-Economic Study of the Biorefinery of Waste from Primary Industrialization of Wood and 
Agroindustrial], Ph.D. Thesis, National University of Misiones, Posadas, Argentina.

Clauser, N. M., Felissia, F. F., Area, M. C., and Vallejos, M. E. (2021). "A framework for the design and analysis of integrated multi-product biorefineries from agricultural and forestry wastes," Renewable and Sustainable Energy Reviews 139, 110687. DOI: 10.1016/j.rser.2020.110687

Coremberg, A. (2018). Medición de la Cadena de Valor de la Bioeconomía en Argentina: Hacia una Cuenta Satelite. Ministerio de Produccion y Trabajo, Buenos Aires, Argentina.

Cotana, F., Cavalaglio, G., Gelosia, M., Nicolini, A., Coccia, V., and Petrozzi, A. (2014). "Production of bioethanol in a second generation prototype from pine wood chips," Energy Procedia 45, 42-51. DOI: 10.1016/j.egypro.2014.01.006

Cristóbal, J., Matos, C. T., Aurambout, J.-P., Manfredi, S., and Kavalov, B. (2016). "Environmental sustainability assessment of bioeconomy value chains," Biomass and Bioenergy 89, 159-171. DOI: 10.1016/j.biombioe.2016.02.002

Dagnino, E. P., Ruiz, C., and Chamorro, E. (2018). "Ensayos preliminares de deslignificación de aserrín de algarrobo negro, en vistas a la producción eficiente de azúcares fermentables," Avances en Energías Renovables y Medio Abiente 22, 61-66.

de Andrade Coutinho, P. L., Morita, A. T., Cassinelli, L. F., Morschbacker, A., and Do Carmo, R. W. (2013). "Braskem's ethanol to polyethylene process development," in: Catalytic Process Development for Renewable Materials, P. Imhof and J. C. van der Waal (eds.), Wiley-VCH, Weinheim, Germany, pp. 149-165.

de Assis, C. A., Gonzalez, R., Kelley, S., Jameel, H., Bilek, T., Daystar, J., Handfield, R., Golden, J., Prestemon, J., and Singh, D. (2017). "Risk management consideration in the bioeconomy," Biofuels, Bioproducts and Biorefining 11(3), 549-566. DOI: $10.1002 / \mathrm{bbb} .1765$

de Jong, E., Higson, A., Walsh, P., and Wellisch, M. (2012a). Biobased Chemicals: Value Added Products from Biorefineries, IEA Bioenergy, Wageningen, Netherlands. de Jong, E., Higson, A., Walsh, P., and Wellisch, M. (2012b). "Product developments in the bio-based chemicals arena," Biofuels, Bioproducts and Bioengineering 6(6), 606624. DOI: $10.1002 / \mathrm{bbb} .1360$

Dias, M. O. S., Modesto, M., Ensinas, A. V, Nebra, S. A., Filho, R. M., and Rossell, C. E. V. (2011). "Improving bioethanol production from sugarcane: Evaluation of distillation, thermal integration and cogeneration systems," Energy 36(6), 3691-3703. DOI: $10.1016 /$ j.energy.2010.09.024

Díaz, J. A. L. (2018). Producción de Bioetanol a Partir de Subproductos de la Industria Vitivinícola. Utilización de Orujos de uva Blanca, Ph.D. Dissertation, National University of Cuyo, Mendoza, Argentina.

Echemi. (2021). "Ethylene glycol (EG) price market analysis." (https://www.echemi.com/productsInformation/pid_Seven2471-ethylene-glycoleg.html), Accessed 23 nov 2020.

Endres, H.-J. (2017). "Bioplastics," in: Biorefineries, K. Wagemann and N. Tippkötter, (eds.), Springer Nature, Cham, Switzerland, pp. 427-468.

Fan, D., Dai, D.-J., and Wu, H.-S. (2013). "Ethylene formation by catalytic dehydration of ethanol with industrial considerations," Materials 6(1), 101-115. DOI: 10.3390/ma6010101

Feng, X., and Huang, R. Y. M. (1997). "Liquid separation by membrane pervoration: A review," Ind. Eng. Chem. Res 36 (4), 1048-1066. DOI: 10.1021/ie960189g

Ferreira, J. A., Brancoli, P., Agnihotri, S., Bolton, K., and Taherzadeh, M. J. (2018). “A 
review of integration strategies of lignocelluloses and other wastes in 1st generation bioethanol processes," Process Biochemistry 75, 173-186. DOI:

10.1016/j.procbio.2018.09.006

Fonseca, G. G., Heinzle, E., Wittmann, C., and Gombert, A. K. (2008). "The yeast Kluyveromyces marxianus and its biotechnological potential," Applied Microbiology and Biotechnology 79(3), 339-354. DOI: 10.1007/s00253-008-1458-6

Frolkova, A. K., and Raeva, V. M. (2010). "Bioethanol dehydration. State of the art," Theoretical Foundations of Chemical Engineering 44(4), 545-556. DOI: $10.1134 / \mathrm{S} 0040579510040342$

Global Market Insights. (2016). Bio-Based Ethylene Market Size, Industry Analysis Report, Regional Outlook, Application Development Potential, Price Trend, Competitive Market Share \& Forecast, 2020-2026, Global Market Insights, Selbyville, DE, USA.

GP Energy (2020). “GP Energy S.A. energía y productos,” (http://gpenergy.com.ar/\#!/bienvenido/), Accessed 10 nov 2020.

Graham, N. B., Zulfiqar, M., Nwachuku, N. W., and Rashid, A. (1989). "Interaction of poly(ethylene oxide) with solvents: 2. Water-poly(ethylene glycol)," Polymer 30(3), 528-533. DOI: 10.1016/0032-3861(89)90026-8

Grassi, A., Buonerba, A., and Sanchez, S. O. (2015). "Bio-sourced polyolefins," in: Biorefineries, M. Aresta, A. Dibenedetto, and F. Dumeignil (eds.), De Gruyter, Berlin, Germany, pp. 165-196.

Gu, H., Zhang, J., and Bao, J. (2014). "Inhibitor analysis and adaptive evolution of Saccharomyces cerevisiae for simultaneous saccharification and ethanol fermentation from industrial waste corncob residues," Bioresource Technology 157, 6-13. DOI: 10.1016/j.biortech.2014.01.060

Hackl, R., Arvidsson, M., Lundin, B., and Harvey, S. (2011). "Process integration study of a biorefinery producing ethylene from lignocellulosic feedstock for a chemical cluster," in: $6^{\text {th }}$ Dubrovnik Conference on Sustainable Development of Energy, Water and Environment Systems, Dubrovnik, Croatia.

Hackl, R., and Harvey, S. (2016). "Design strategies for integration of biorefinery concepts at existing industrial process sites: Case study of a biorefinery producing ethylene from lignocellulosic feedstock as an intermediate platform for a chemical cluster," in: Process Design Strategies for Biomass Conversion Systems, Denny K. S. $\mathrm{Ng}$, Raymond R. Tan, Dominic C. Y. Foo, and Mahmoud M. El-Halwagi (eds.), First Edition. John Wiley \& Sons, pp. 77-102.

Hahn-Hägerdal, B., Galbe, M., Gorwa-Grauslund, M. F., Lidén, G., and Zacchi, G. (2006). "Bio-ethanol - The fuel of tomorrow from the residues of today," Trends in Biotechnology 24(12), 550-556. DOI: 10.1016/j.tibtech.2006.10.004

Hall, K. (2020). "Ethylene and propylene prices in 2020: Two market stories," (http://blog.opisnet.com/ethylene-propylene-prices-2020), Accessed 12 nov 2020.

Haro, P., Ollero, P., and Trippe, F. (2013). "Technoeconomic assessment of potential processes for bio-ethylene production," Fuel Processing Technology 114, 35-48. DOI: 10.1016/j.fuproc.2013.03.024

Hettinga, W. G., Junginger, H. M., Dekker, S. C., Hoogwijk, M., McAloon, A. J., and Hicks, K. B. (2009). "Understanding the reductions in US corn ethanol production costs: An experience curve approach," Energy Policy 37(1), 190-203. DOI: 10.1016/j.enpol.2008.08.002

Hottle, T. A., Bilec, M. M., and Landis, A. E. (2013). "Sustainability assessments of bio- 
based polymers," Polymer Degradation and Stability 98(9), 1898-1907. DOI:

10.1016/j.polymdegradstab.2013.06.016

Hu, Y., Zhan, N., Dou, C., Huang, H., Han, Y., Yu, D., and Hu, Y. (2010). "Selective dehydration of bio-ethanol to ethylene catalyzed by lanthanum-phosphorous-modified HZSM-5: Influence of the fusel," Biotechnology Journal 5(11), 1186-1191. DOI: 10.1002/biot.201000139

Huang, R., Su, R., Qi, W., and He, Z. (2011). "Bioconversion of lignocellulose into bioethanol: Process intensification and mechanism research," Bioenergy Research 4(4), 225-245. DOI: 10.1007/s12155-011-9125-7

ICIS. (2010). "Ethylene uses and market data," (https://www.icis.com/explore/resources/news/2007/11/05/9075777/ethylene-usesand-market-data), Accessed 12 nov 2020.

ICIS. (2013). "Chemical proile: US ethylene glycol," (https://www.icis.com/explore/resources/news/2013/03/08/9647891/chemical-profileus-ethylene-glycol/), Accessed 12 nov 2020.

ICIS. (2019). "Polyethylene prices, news and analysis," (https://www.icis.com/explore/commodities/chemicals/polyethylene/), Accessed 12 nov 2020.

ICIS. (2020). "Olefins prices, markets \& analysis," (https://www.icis.com/explore/commodities/chemicals/olefins/), Accessed 12 nov 2020.

Ita-Nagy, D., Vázquez-Rowe, I., Kahhat, R., Quispe, I., Chinga-Carrasco, G., Clauser, N. M., and Area, M. C. (2020). "Life cycle assessment of bagasse fiber reinforced biocomposites," Science of the Total Environment 720, 137586. DOI: 10.1016/j.scitotenv.2020.137586

Iwata, T. (2015). "Biodegradable and bio-based polymers: Future prospects of ecofriendly plastics," Angewandte Chemie 54(11), 3210-3215. DOI: 10.1002/anie. 201410770

Jiang, P., Parvez, A. M., Meng, Y., Xu, M.-X., Shui, T.-c., Sun, C.-g., and Wu, T. (2019). "Exergetic, economic and carbon emission studies of bio-olefin production via indirect steam gasification process," Energy 187, 115933. DOI: 10.1016/j.energy.2019.115933

Kagyrmanova, A. P., Chumachenko, V. A., Korotkikh, V. N., Kashkin, V. N., and Noskov, A. S. (2011). "Catalytic dehydration of bioethanol to ethylene: Pilot-scale studies and process simulation," Chemical Engineering Journal 176-177, 188-194. DOI: 10.1016/j.cej.2011.06.049

Kang, Q., Appels, L., Baeyens, J., Dewil, R., and Tan, T. (2014a). "Energy-efficient production of cassava-based bio-ethanol," Advances in Bioscience and Biotechnology 5, 925-939. doi: 10.4236/abb.2014.512107

Kang, Q., Appels, L., Tan, T., and Dewil, R. (2014b). "Bioethanol from lignocellulosic biomass: Current findings determine research priorities," The Scientific World Journal 298153, 1-13. DOI: 10.1155/2014/298153

Keller, N., Ducamp, M. N., Robert, D., and Keller, V. (2013). "Ethylene removal and fresh product storage: A challenge at the frontiers of chemistry. Toward an approach by photocatalytic oxidation," Chemical Review 113, 5029-5070. DOI: $10.1021 / \mathrm{cr} 900398 \mathrm{v}$

Kikuchi, Y., Oshita, Y., Mayumi, K., and Hirao, M. (2017). “Greenhouse gas emissions and socioeconomic effects of biomass-derived products based on structural path and 
life cycle analyses: A case study of polyethylene and polypropylene in Japan," Journal of Cleaner Production 167, 289-305. DOI: 10.1016/j.jclepro.2017.08.179

Kniel, L., Winter, O., and Stork, K. (1980). Ethylene: Keystone to the Petrochemical Industry, CRC Press, Boca Raton, FL, USA.

Körte, A. C. (2019). Informe Sobre la Factibilidad del Aprovechamiento de la Biomasa Forestal de Campo [Report on the Feasability of using Forest Biomass in the Field] (Technical Reports Collection No. 7), Food and Agriculture Organization of the United Nations, Buenos Aires, Argentina.

Kruyeniski, J. (2017). Influencia del Pretratamiento de Residuos Forestoindustriales sobre la Producción de Bioetanol [Influence of Pretreatment of Forestry-Industrial Waste on Bioethanol Production], Ph.D. Thesis, National University of Misiones, Posadas, Argentina.

Kruyeniski, J., Felissia, F. E., and Area, M. C. (2017). "Pretratamiento soda-etanol de pino y su influencia en la hidrólisis enzimática [Pretreatment soda-ethanol of pine and its influence on enzymatic hydrolysis]," Revista de Ciencia y Tecnología 19(28), 3741.

Kruyeniski, J., Ferreira, P. J. T., Carvalho, M. G. V. S., Vallejos, M. E., Felissia, F. E., and Area, M. C. (2019). "Physical and chemical characteristics of pretreated pine sawdust and its enzymatic hydrolysis," Industrial Crops \& Products 130, 528-536. DOI: 10.1016/j.indcrop.2018.12.075

Kumari, D., and Singh, R. (2018). "Pretreatment of lignocellulosic wastes for biofuel production: A critical review," Renewable and Sustainable Energy Reviews 90, 877891. DOI: 10.1016/j.rser.2018.03.111

Kuosmanen, T., Kuosmanen, N., El-Meligi, A., Ronzon, T., Gurria, P., Lost, S., and M'Barek, R. (2020). How Big is the Bioeconomy? Reflections from an Economic Perspective (JRC120324), Publications Office of the European Union, Luxembourg, Luxembourg.

Laharrague, N. (2018). Censo Nacional de Aserraderos, Dirección Nacional de Desarrollo Foresto Industrial, Misiones, Argentina.

Liptow, C., Tillman, A.-M., and Janssen, M. (2015). "Life cycle assessment of biomassbased ethylene production in Sweden - Is gasification or fermentation the environmentally preferable route?," The International Journal of Life Cycle Assessment 20, 632-644. DOI: 10.1007/s11367-015-0855-1

Manfredi, A. P., Ballesteros, I., Sáez, F., Perotti, N. I., Martínez, M. A., and Negro, M. J. (2018). "Integral process assessment of sugarcane agricultural crop residues conversion to ethanol," Bioresource Technology 260, 241-247. DOI: 10.1016/j.biortech.2018.03.114

Manikandan, N. A., Kumar, R. V., Pugazhenthi, G., and Pakshirajan, K. (2016). "Biorefinery and possible deforestation," in: Platform Chemical Biorefinery, S. K. Brar, S. J. Sarma, and K. Pakshirajan (eds.), Elsevier, Amsterdam, Netherlands, pp. 307-322.

Martinz, D., and Quadros, J. (2008). "Compounding PVC with renewable materials," Plastics, Rubber and Composites: Macromolecular Engineering 37(9-10), 459-464. DOI: $10.1179 / 174328908 X 362917$

McKechnie, J., Pourbafrani, M., Saville, B. A., and MacLean, H. L. (2015). "Environmental and financial implications of ethanol as a bioethylene feedstock versus as a transportation fuel," Environmental Research Letters 10(12), 124018. DOI: $10.1088 / 1748-9326 / 10 / 12 / 124018$ 
Melander, A. N., and Qvint, K. (2016). Assessing the Sustainability of First Generation Ethanol for Bioethylene Production, Master's Thesis Chalmers University of Technology, Gothenburg, Sweden.

Mendes, C. V. T., Vergara, P., Carbajo, J. M., Villar, J. C., Rocha, J. M. S., and Carvalho, M. G. V. S. (2020). "Bioconversion of pine stumps to ethanol: Pretreatment and simultaneous saccharification and fermentation," Holzforschung 74(2), 212-216. DOI: $10.1515 / \mathrm{hf}-2018-0126$

Mendieta, C. M. (2020). "Bioetanol 2G a partir de las estrategias HFS y SFS [2G bioethanol from the SHF and SSF strategies]," El Papel 213, 42-43.

Mendieta, C. M., Vallejos, M. E., Felissia, F. E., Chinga-Carrasco, G., and Area, M. C. (2019). "Review: Bio-polyethylene from wood wastes," Journal of Polymers and the Environment 28(1), 1-16. DOI: 10.1007/s10924-019-01582-0

Mendoza-Pedroza, J. J., and Segovia-Hernandez, J. G. (2018). “Alternative schemes for the purification of bioethanol: A comparative study," Recent Advances in Petrochemical Science 4(2), 0024-0032. DOI: 10.19080/RAPSCI.2018.04.555631

Meneses, T. M. S. (2018). Autohidrólisis y Deslignificación Organosolv de Madera de Pinus Radiata para la Recuperación de Hemicelulosas y Lignina con Aprovechamiento de la Fracción Celulósica por vía Enzimática, Master's Thesis, Complutense University of Madrid, Spain.

Mestre, M. V. (2018). "Bioeconomía: El diseño de un cambio de rumbo [Bioeconomy; Designing a change of course]," Ambienta: La revista del Ministerio de Medio Ambiente 125, 50-67.

Min-hee, J. (2019). "Ethylene prices plummet, hitting a low in 4 and half years," Business Korea, (http://www.businesskorea.co.kr/news/articleView.html?idxno=32779\#: :text=The\% 20price $\% 20$ of $\% 20$ ethylene $\% 2 \mathrm{C} \% 20$ one,naphtha $\% 20$ cracking $\% 20$ centers $\% 20$ (NCCs) .), Accessed 26 nov 2020.

Mohsenzadeh, A., Zamani, A., and Taherzadeh, M. J. (2017). "Bioethylene production from ethanol: A review and techno-economical evaluation," ChemBioEng Reviews 4(2), 75-91. DOI: 10.1002/cben.201600025

Montoro, M. L., Herrero, M., Mamaní, A., Sardella, M., Vallejo, M., and Deiana, A. (2020). "Effects of pretreatments on the bioavailability of sugars on discarded melons to obtain bioethanol," Research Square 1-20. DOI: 10.21203/rs.3.rs-21228/v1

Moon, S., Chae, H.-J., and Park, M. B. (2019). "Dehydration of bioethanol to ethylene over H-ZSM-5 catalysts: A scale-up study,” Catalysts 9(6), 186-197. DOI: $10.3390 /$ catal9020186

Morales, M., Quintero, J., Conejeros, R., and Aroca, G. (2015). "Life cycle assessment of lignocellulosic bioethanol: Environmental impacts and energy balance," Renewable and Sustainable Energy Reviews 42, 1349-1361. DOI: 10.1016/j.rser.2014.10.097

Morschbacker, A. (2009). "Bio-ethanol based ethylene," Polymer Reviews 49(2), 79-84. DOI: $10.1080 / 15583720902834791$

Moser, B. (2013). "Dow and Mitsui postpone sugarcane polymer plant," Plastics News, (https://www.plasticsnews.com/article/20130110/NEWS/301109988/dow-and-mitsuipostpone-sugarcane-polymer-plant), Accessed 03 dec 2020.

Näyhä, A. (2012). Towards Bioeconomy A Three-Phase Delphi Study on Forest Biorefinery Diffusion in Scandinavia and North America, Ph.D. Thesis, Unversity of Jyväskylä, Jyväskylä, Finland.

Nguyen, L. K., Na, S., Hsuan, Y. G., and Spatari, S. (2020). "Uncertainty in the life cycle 
greenhouse gas emissions and costs of HDPE pipe alternatives," Resources, Conservation and Recycling 154, 104602. DOI: 10.1016/j.resconrec.2019.104602

Nhien, L. C., Long, N. V. D., and Lee, M. (2017). "Novel heat-integrated and intensified biorefinery process for cellulosic ethanol production from lignocellulosic biomass," Energy Conversion and Management 141, 367-377. DOI:

10.1016/j.enconman.2016.09.077

Nitzsche, R., Budzinski, M., and Gröngröft, A. (2016). "Techno-economic assessment of a wood-based biorefinery concept for the production of polymer-grade ethylene, organosolv lignin and fuel," Bioresource Technology 200, 928-939. DOI: 10.1016/j.biortech.2015.11.008

Nizami, A. S., Rehan, M., Waqas, M., Naqvi, M., Ouda, O. K. M., Shahzad, K., Miandad, R., Khan, M. Z., Syamsiro, M., Ismail, I. M. I., et al. (2017). "Waste biorefineries: Enabling circular economies in developing countries," Bioresource Technology 241, 1101-1117. DOI: 10.1016/j.biortech.2017.05.097

Noticias, A. U. (2010). "Chaco: Una planta producirá combustible a partir de los residuos de aserraderos," Argentina Forestal, (https://www.argentinaforestal.com/2010/03/05/chaco-una-planta-producirombustible-a-partir-de-los-residuos-de-aserraderos/), Accessed 03 dec 2020.

Oliveira, C. C. N., Rochedo, P. R. R., Bhardwaj, R., Worrell, E., and Szklo, A. (2019). "Bio-ethylene from sugarcane as a competitiveness strategy for the Brazilian chemical industry," Biofuels, Bioproducts and Biorefining 14(2), 286-300. DOI: 10.1002/bbb.2069

Oliveira, C. M., Cruz, A. J. G., and Costa, C. B. B. (2016). "Improving second generation bioethanol production in sugarcane biorefineries through energy integration," Applied Thermal Engineering 109(A), 819-827. DOI: 10.1016/j.applthermaleng.2014.11.016

Oliveira, C. M., Pavão, L. V., Ravagnani, M. A. S. S., Cruz, A. J. G., and Costa, C. B. B. (2018). "Process integration of a multiperiod sugarcane biorefinery," Applied Energy 213, 520-539. DOI: 10.1016/j.apenergy.2017.11.020

Olofsson, K., Bertilsson, M., and Lidén, G. (2008). "A short review on SSF - An interesting process option for ethanol production from lignocellulosic feedstocks," Biotechnology for Biofuels 1(7), 1-14. DOI: 10.1186/1754-6834-1-7

Organización de las Naciones Unidas. (2015). "Objetivos de desarrollo sostenible," (https://www.un.org/sustainabledevelopment/es/objetivos-de-desarrollo-sostenible/), Naciones Unidas, Accessed 04 dec 2020.

Ouyang, J., Kong, F., Su, G., Hu, Y., and Song, Q. (2009). "Catalytic conversion of bioethanol to ethylene over la-modified HZSM-5 catalysts in a bioreactor," 132, 64-74. DOI: $10.1007 / \mathrm{s} 10562-009-0047-3$

Palmqvist, E., and Hahn-Hägerdal, B. (2000). "Fermentation of lignocellulosic hydrolysates I: Inhibitors and mechanism of inhibition," Bioresource Technology 74(1), 25-33.

Pardo, L. M. F., Galán, J. E. L., and Ramírez, T. L. (2018). "Saccharide biomass for biofuels, biomaterials, and chemicals," in: Biomass and Green Chemistry, S. Vaz (ed.), Springer International Publishing, Cham, Switzerland, pp. 11-30.

Peirano, C., Bussio, D., and Varela, A. B. (2019). Plan Estratégico Forestal y ForestoIndustrial Argentina 2030 [Strategic Forestry and Forestry-Industrial Plan Argentina 2030], Ministry of Agriculture Livestock and Fisheries, Argentina.

Pérez, V., Pascual, A., Rodrigo, A., García-Torreiro, M., Latorre-Sánchez, M., Lozano, C. C., Moreno, A. D., Dominguez, J. M. O., Serna-Maza, A., García, N. H., et al. 
(2020). "Integrated innovative biorefinery for the transformation of municipal solid waste into biobased products," in: Waste Biorefinery, T. Bhaskar, A. Pandey, E. Rene, and D. Tsang (eds.), Elsevier, Amsterdam, Netherlands, pp. 41-80.

Petri, G., Borodowski, E., von Haeften, C., Funes, L. S., Barreiro, E., Arroyo, C. M., French, G., de Igarzábal, P., Vera, L. S., et al. (2018). Censo Nacional de Aserraderos 2015, Ministerio de Agroindustria, Chaco, Argentina, (https://magyp.gob.ar/sitio/areas/ss_desarrollo_foresto_industrial/censos_inventario/ _archivos/censo//000000_Provincia\%20de\%20Chaco\%20(Julio\%202018).pdf), Accessed 03 December 2020.

Petri, G., Borodowski, E., von Haeften, C., Funes, L. S., Linares, C., Jara, H. D., Barreiro, E., Moruzzi, C., and Lavignolle, J. (2016). Censo Nacional de Aserraderos 2015, Ministerio de Agroindustria, Formosa, Argentina, (https://www.magyp.gob.ar/sitio/areas/ss_desarrollo_foresto_industrial/censos_invent ario/_archivos/censo//000000_Provincia\%20de\%20Formosa\%20(Octubre\%202016). pdf), Accessed 03 December 2020.

PinoPack. (2020). "Pino Pack: Empresa dedicada a la innovación y la creatividad en productos para mascotas," Pino Pack, (http://pinopack.com.ar/). Accessed $04 \mathrm{dec}$ 2020.

Ramesh, K., Jie, C., Han, Y.-F., and Borgna, A. (2010). "Synthesis, characterization, and catalytic activity of phosphorus modified H-ZSM-5 catalysts in selective ethanol dehydration," Industrial \& Engineering Chemistry Research 49(9), 4080-4090. DOI: 10.1021/ie901666f

Rodríguez, M. D., Castrillo, M. L., Velázquez, J. E., Kramer, G. R., Sedler, C., Zapata, P. D., and Villalba, L. (2017). "Obstención de azucares fermentables a partir de aserrín de pino pretratado secuencialmente con ácido-base [Obtaining fermentable sugars from pine saw dust sequentially pre-treated with acid-base]," Revista Internacional de Contaminación Ambiental 33(2), 317-324. DOI: 10.20937/RICA.2017.33.02.12

Rosales-Calderon, O., and Arantes, V. (2019). "A review on commercial-scale high-value products that can be produced alongside cellulosic ethanol," Biotechnology for Biofuels 12(240). DOI: 10.1186/s13068-019-1529-1

Rossetti, I., Compagnoni, M., Finocchio, E., Ramis, G., Michelle, A. D., Millot, Y., and Dzwigaj, S. (2017). "Ethylene production via catalytic dehydration of diluted bioethanol: A step towards an integrated biorefinery," Applied Catalysis B: Environmental 210, 407-420. DOI: 10.1016/j.apcatb.2017.04.007

Saha, B. C. (2003). "Hemicellulose bioconversion," Journal of Industrial Microbiology and Biotechnology 30(5), 279-291. DOI: 10.1007/s10295-003-0049-X

Santagata, C., Iaquaniello, G., Salladini, A., Agostini, E., Capocelli, M., and Falco, M. D. (2020). "Production of low-density poly-ethylene (LDPE) from chemical recycling of plastic waste: Process analysis," Journal of Cleaner Production 253, 119837. DOI: 10.1016/j.jclepro.2019.119837

Santos-Panqueva, Y., Guerrero-Fajardo, C. A., Cuevas-Rodriguez, E. O., Picos-Corrales, L. A., Silva, C. M., and Contreras-Andrade, I. (2017). "Production of bio-ethylene from wastes of microalgae to biodiesel biorefinery," Waste and Biomass Valorization 10(2), 377-386. DOI: 10.1007/s12649-017-0064-1

Sharma, B., Larroche, C., and Dussap, C. G. (2020). "Comprehensive assessment of 2G bioethanol production," Bioresource Technology 313, 1-39. DOI:

10.1016/j.biortech.2020.123630

Sheng, Q., Ling, K., Li, Z., and Zhao, L. (2013). "Effect of steam treatment on catalytic 
performance of HZSM-5 catalyst for ethanol dehydration to ethylene," Fuel

Processing Technology 110, 73-78. DOI: 10.1016/j.fuproc.2012.11.004

Silva-Ortiz, P. A., Marechál, F., and De Oliveira Junior, S. (2020). "Exergy assessment and techno-economic optimization of bioethanol production routes," Fuel 279, 1-24. DOI: $10.1016 /$ j.fuel.2020.118327

Spencer, D. B. (1994). "Recycling - Household waste," in: Encyclopedia of Materials: Science and Technology, K. H. W. Buschow, R. W. Cahn, M. C. Flemings, B. Ilschner, E. J. Kramer, S. Mahajan, and P. Veyssière (eds.), Elsevier, Amsterdam, Netherlands, pp. 1-9.

Stoffel, R. B. (2016). Pine Sawdust Fractionation for a Forest Biorefinery, Ph.D. Thesis, National University of Misiones, Posadas, Argentina.

Taylor, R., Nattrass, L., Alberts, G., Robson, P., Chudziak, C., Bauen, A., Libelli, I. M., Lotti, G., Prussi, M., Nistri, R., et al. (2015). (Report No. ENER/C2/4232012/SI2.673791). European Commission Directorate-General Energy.

Thakur, S., Verma, A., Sharma, B., Chaudhary, J., Tamulevicius, S., and Thakur, V. K. (2018). "Recent developments in recycling of polystyrene based plastics," Current Opinion in Green and Sustainable Chemistry 13, 32-38. DOI: 10.1016/j.cogsc.2018.03.011

The National Academies of Science, Engineering, and Medicine. (2020). Safeguarding the Bioeconomy, The National Academies Press, Washington, DC.

Tripodi, A., Belotti, M., and Rossetti, I. (2019). "Bioethylene production: From reaction kinetics to plant design," ACS Sustainable Chemistry \& Engineering 7(15), 13333 13350. DOI: 10.1021/acssuschemeng.9b02579

Uasuf, A., and Hilbert, J. A. (2012). El uso de la biomasa de Origen Forestal con destino a bioenergía en la Argentina, National Institute of Agricultural Technology, Buenos Aires, Argentina.

Valderrama, C., Quintero, V., and Kafarov, V. (2020). "Energy and water optimization of an integrated bioethanol production process from molasses and sugarcane bagasse: A Colombian case," Fuel 260, 116314. DOI: 10.1016/j.fuel.2019.116314

Valenzuela, R., Priebe, X., Troncoso, E., Ortega, I., Parra, C., and Freer, J. (2016). "Fiber modifications by organosolv catalyzed with $\mathrm{H}_{2} \mathrm{SO}_{4}$ improves the SSF of Pinus radiata," Industrial Crops and Products 86, 79-86. DOI: 10.1016/j.indcrop.2016.03.037

Vallejos, M. E., Kruyeniski, J., and Area, M. C. (2017). "Second-generation bioethanol from industrial wood waste of South American species," Biofuel Research Journal 4(3), 654-667. DOI: 10.18331/BRJ2017.4.3.4

Vargas, R., and Vecchietti, A. (2018). "Modeling the thermochemical pretreatment of Eucalyptus globulus for bioethanol production," Industrial \& Engineering Chemistry Research 57(37), 12458-12467. DOI: 10.1021/acs.iecr.8b02706

von Schenck, A., Berglin, N., and Uusitalo, J. (2013). "Ethanol from Nordic wood raw material by simplified alkaline soda cooking," Applied Energy 102, 229-240. DOI: 10.1016/j.apenergy.2012.10.003

Wagner, H., and Kaltschmitt, M. (2013). "Biochemical and thermochemical conversion of wood to ethanol-simulation and analysis of different processes," Biomass Conv. Bioref. 3 (2), 87-103. DOI: 10.1007/s13399-012-0064-0

Werpy, T., and Petersen, G. (2004). Top Value Added Chemicals from Biomass: Volume I - Results of Screening for Potential Candidates from Sugars and Synthesis Gas (DOE/GO-102004-1992), National Renewable Energy Laboratory, Golden, CO. 
Wierny, M., Coremberg, A., Costa, R., Trigo, E., and Marcelo, R. (2015). Medición de la Bioeconomía: Cuantificación del Caso Argentino, Buenos Aires, Argentina.

Wiley-VCH. (2016). Ullmann's Polymers and Plastics. Products and Processes, WileyVCH, Weinheim, Germany.

Wingren, A., Galbe, M., and Zacchi, G. (2003). "Techno-economic evaluation of producing ethanol from softwood: Comparison of SSF and SHF and identification of bottlenecks," Biotechnology Progress 19(4), 1109-1117. DOI: 10.1021/bp0340180

Wu, C.-Y., and Wu, H.-S. (2017). "Ethylene formation from ethanol dehydration using ZSM-5 catalyst,” ACS Omega 2(8), 4287-4296. DOI: 10.1021/acsomega.7b00680

Wyman, C. E., Charles, C. M., and Kumar, R. (2017). "Bioethanol from lignocellulosic biomass," Encyclopedia of Sustainability Science and Technology, Springer Science+Business Media LLC 2017, New York, NY. DOI: 10.1007/978-1-49397813-7

Ximenes, E., Kim, Y., Mosier, N., Dien, B., and Ladisch, M. (2011). "Deactivation of cellulases by phenols," Enzyme and Microbial Technology 48(1), 54-60. DOI: 10.1016/j.enzmictec.2010.09.006

Yakovleva, I. S., Banzaraktsaeva, S. P., Ovchinnikova, E. V., Chumachenko, V. A., and Isupova, L. A. (2016). "Catalytic dehydration of bioethanol to ethylene," Catalysis in Industry 8(2), 152-167. DOI: 10.1134/S2070050416020148

Yanase, S., Hasunuma, T., Yamada, R., Tanaka, T., Ogino, C., Fukuda, H., and Kondo, A. (2010). "Direct ethanol production from cellulosic materials at high temperature using the thermotolerant yeast Kluyveromyces marxianus displaying cellulolytic enzymes," Applied Microbiology and Biotechnology 88(1), 381-388. DOI: 10.1007/s00253-010-2784-z

Zacharopoulou, V., and Lemonidou, A. (2017). "Olefins from biomass intermediates: A review," Catalysts 8(1), 1-19. DOI: 10.3390/catal8010002

Zhang, X., Wang, R., Yang, X., and Zhang, F. (2008). "Comparison of four catalysts in the catalytic dehydration of ethanol to ethylene," Microporous and Mesoporous Materials 116(1-3), 210-215. DOI: 10.1016/j.micromeso.2008.04.004

Zhu, M.-J., Zhu, Z.-S., and Li, X.-H. (2011). "Bioconversion of paper sludge with low cellulosic content to ethanol by separate hydrolysis and fermentation," African Journal of Biotechnology 10(66), 15072-15083. DOI: 10.5897/AJB11.1644

Zimmermann, H., and Walzl, R. (2000). "Ethylene," in: Ullmann's Encyclopedia of Industrial Chemistry, Wiley-VCH, Weinheim, Germany, 1-58. DOI: $10.1002 / 14356007$

Article submitted: January 23, 2021; Peer review completed: March 6, 2021; Revised version received and accepted: March 19, 2021; Published: March 25, 2021.

DOI: 10.15376/biores.16.2.Mendieta 